\title{
DIE SOMALILAND BURGHER CONTINGENT
}

\author{
G. GENIS \\ DIREKTORAAT DOKUMENTASIEDIENS, SANW
}

\begin{abstract}
The Somaliland Burgher Contingent, consisting of Afrikaans and English speaking South Africans, was the first South African volunteer unit who fought on foreign soil. Volunteers hailed not only from South Africa but from Britain, Rhodesia, America, Ireland, Scotland, Canada and Austria as well. This truly cosmopolitan unit fought during the Third Expedition (1902-1903) in Somaliland against Mohammed Abdulle Hassan (1856-1920) - the so-called Mad Mullah. During this expedition the South Africans fought side by side with British troops of the King's Royal Rifle Corps, Indian troops and the King's African Rifles whose members consisted of Somalis, Sikhs, Sudanese and Yaos (Africans). These troops endured many hardships during the campaign: they had to march in extreme heat in thick bush country with meager rations and water. The Somaliland Burgher Contingent was involved in skirmishes with the Dervish forces of the Mullah but not in the disasters of Gumburu and Daratoleh during which two British forces were cut up. The Third Expedition was a military failure for the British and a victory for the Mullah who wanted to rid his country of the British infidel. The Mullah resisted British and Abysinian intrigues in his country until his death in 1920. Apart from the campaign, the composition, character, mobilization, demobilization and compensation of the Somaliland Burgher Contingent as well as the reasons why volunteers joined up, are discussed.
\end{abstract}

\section{Inleiding}

Die opvatting word soms gehuldig dat die Eerste Wêreldoorlog (1914-1918) die eerste kampanje was waartydens Suid-Afrikaanse soldate buite die grense van Suid-Afrika geveg het. Die Derde Britse Ekspedisie teen Mohammed Abdulle Hassan (1856-1920) - die sogenaamde Mal Mullah - van Somaliland, wat vanaf 4 November 1902 tot 3 Julie 1903 geduur het, was egter die eerste veldtog buite die grense van Suid-Afrika waaraan Suid-Afrikaners deelgeneem het. Die Suid-Afrikaanse kontingent het bestaan uit ' $n$ kompanjie van die King's Royal Rifle Corps - ' $n$ Britse eenheid wat gedurende die Anglo-Boereoorlog in Suid-Afrika geveg het - en die Somaliland Burgher Contingent. Laasgenoemde was ' $n$ vrywilligerkorps wat vir slegs ses maande opgeroep is. ${ }^{1}$

Sekere offisiële Britse bronne verwys dikwels na die Somaliland Burgher Contingent as ' $\mathrm{n}$ Boer Con- tingent wat daarop dui dat dit moontlik die begeerte van die Britse owerhede was om slegs Boere en Afrikaanssprekendes in die kontingent op te neem. Laasgenoemde was egter nie die geval nie. Die kontingent het uit Boere, Engelssprekende SuidAfrikaners, Engelse, Rhodesiërs, Amerikaners, Skotte, lere, Kanadese en 'n Oostenryker bestaan. Hierdie kontingent was dus ' $n$ ware heterogene eenheid wat vir Brittanje in Somaliland gaan veg het. $^{2}$

Ongeveer ' $n$ kwart van die kontingent van tussen 89 en 109 lede, het uit Boere bestaan wat tydens die Anglo-Boereoorlog (1899-1902) teen Groot Brittanje geveg het. In Somaliland moes hierdie Boere skouer aan skouer saam met hul eertydse vyand veg. Ander mede-krygers het ook swart Afrikane, Indiërs en selfs 'n paar "hensoppers", dit wil sê Boere wat vroeg gedurende die AngloBoereoorlog oorgegee het, ingesluit. Laasgenoemde is deur die "bittereinders" of Boere wat tot aan

General Staff War Office, Official History of the Operations in Somaliland, 1901-1904, vol I, pp 109-198,200; L.L. Gordon, British Battles and Medals, 4th ed, p 304; I.S. Hallows, Regiments and Corps of the British Army, pp 234-235.

Nasionale Argiefbewaarplek (hierna NAB), Pretoria: Argiewe van die Sekretaris van die Goewerneur van Transvaal Kolonie 19011910 (GOV), Houer 629, Lêer PS 401, Somaliland. Export of sheep to the Transvaal, Somaliland Contingent (hierna: NAB: GOV 629 PS 401), Captain Walter Bonham - The Military Secretary to His Excellency The High Commissioner South Africa, Upper Sheikh, Somaliland, 1 June 1903; Ibid, Transvaal No 665, Arthur Lawley - The Right Honourable Joseph Chamberlain MP The Colonial Office London, Governor's Office Johannesburg, 12 September 1903; GOV 629 PS 401, Transvaal No 865, 0165/3095 (MS3), Guy Fleetwood Wilson - The Under Secretary of State Colonial Office, War Office London SW, 30 July 1903; Official History, vol I, p 120. 
die einde van die oorlog teen Brittanje geveg het, verag. Afrikanerlede van die kontingent het dus nie alleenlik saam met die gehate kakies en "hensoppers", wat sy mede-volksgenote tydens die Anglo-Boereoorlog "verraai" het, geveg nie, maar ook saam met swartes wat deur die Afrikaner van die vroeg twintigste eeu as ' $n$ minderwaardige ras

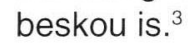

In Somaliland sou die Somaliland Burgher Contingent te staan kom teen die Mullah, 'n Moslemprofeet en nasionalis, wat vasberade was om sy mense en geloof van vreemde - Britse - oorheersing en invloede te bevry. ${ }^{4}$

\section{Samestelling en karakter van die Somaliland Burgher Contingent}

\begin{abstract}
Die bronne stem nie ooreen oor die grootte van die Somaliland Burgher Contingent nie; die getalle wat verstrek word wissel van 89 tot 109. Die drie naamlyste wat die name van die kontingent bevat, dui die getalle respektiewelik as 89, 98 en 109 aan terwyl die Official History of the Operations in Somaliland en The Mad Mullah of Somaliland aandui dat die kontingent 100 man sterk was. Daarteenoor beweer Angus Hamilton, die Reutersoorlogskorrespondent tydens die derde veldtog teen die Mullah, in sy boek Somaliland dat die kontingent 105 man sterk was. ${ }^{5}$
\end{abstract}

Vrywilligers is van oor die hele Suid-Afrika en selfs van oorsee gewerf om by die Somaliland Burgher Contingent aan te sluit. Ongeveer ' $\mathrm{n}$ derde van die vrywilligers het van die Transvaal Kolonie (die vooroorlogse Suid-Afrikaanse Republiek), gekom en on- geveer ' $n$ kwart van die lede was in die Oranje-rivier Kolonie (vooroorlogse Oranje Vrystaat) woonagtig. ${ }^{6}$ 'n Paar vrywilligers het uit die Natal en Kaap Kolonies gekom. ${ }^{7}$ Vyf en twintig lede was buitelanders en dit het twaalf Engelse, drie Amerikaners, drie Rhodesiërs, twee Skotte, twee lere, twee Kanadese en een Oostenryker ingesluit. ${ }^{8}$

Die Suid-Afrikaanse lede van die Burgher Contingent het nie uitsluitlik uit Boerekrygers en Afrikaanssprekendes bestaan nie. As die volledigste naamlys ontleed word, blyk dit dat slegs 39 lede tipiese Afrikaanse vanne gehad het. As in aanmerking geneem word dat sekere Engelssprekendes, Afrikaanse skuilname gebruik het toe hulle by die kontingent aangesluit het, is dit duidelik dat minder as vyftig persent van die lede van die kontingent Afrikaanssprekendes was. Arthur Elderton, ' $n$ lid van die kontingent, het gereken dat die helfte van die lede Engelse was wat Afrikaanse skuilname gebruik het. Dié lid het self die naam Petrus van der Merwe gebruik terwyl hy diens in Somaliland verrig het. ${ }^{9}$ Die Engelssprekende lede wat Afrikaanse skuilname gebruik het, het dit moontlik gedoen omdat hulle gedink het dat dit hul kanse sou verbeter om tot die kontingent toegelaat te word aangesien dit blyk dat die Britse regering ' $n$ Boer Contingent tot stand wou bring.

Elderton was een van ses Engelssprekende lede wat Afrikaanse skuilname gebruik het. Die Amerikaner genaamd Reed van Portland, Oregon het die naam W.F. de Beer gebruik, die Engelsman D. McGleish het die alias D. de Kock aangeneem. Nog 'n Engelsman, P. Griffin het die naam P. Moojen gebruik. ' $n$ Inwoner van Bulawayo in die voormalige Rhodesië (tans Zimbabwe) het sy naam na W. De

NAB, Pretoria: GOV 629 PS 401, Captain Walter Bonham - The Military Secretary to His Excellency The High Commissioner South Africa, Upper Sheikh, Somaliland, 1 June 1903; F. Pretorius, Kommandolewe tydens die Anglo-Boereoorlog 1899-1902, p 282; Official History, vol I, pp 109-198.

Abdi Sheik-Abdi, Divine Madness: Mohammed Abdulle Hassan (1856-1920), pp 47-48,56,58-59,60,207,211. Die Mullah was nie alleenlik' $n$ soldaat nie maar ook ' $n$ bekwame digter.

NAB, Pretoria: GOV 629 PS 401, Captain Walter Bonham - The Military Secretary to His Excellency The High Commissioner South Africa, Upper Sheikh, Somaliland, 1 June 1903 [Dié naamlys wat deur kaptein Walter Bonham, die bevelvoerder van die kontingent opgestel is, en wat die grootte van die kontingent as 89 aandui, bevat die meeste inligting oor die lede van die kontingent aangesien hy die beroepe en karaktertrekke van lede bespreek]; Ibid, Commander Natal District - The Secretary to the High Commissioner Pretoria, Head Office Natal District, Pietermaritzburg, 21 July 1903; NAB, Pretoria: Argiewe van die Luitenant-goewerneur van Transvaal Kolonie 1902-1907 (hierna LTG), Houer 114, Saamgebind met Minute No 155/04, No 4123, Somaliland Contingent, 29 August 1903 [Laasgenoemde bron dui die grootte van die kontingent as 105 aan]; Ibid, Lêer 102/3, vol II, (Somaliland Matters, Boer Gratuity), Nominal Roll Somaliland Burgher Contingent ['n Deel van laasgenoemde naamlys is weggeskeur]; Official History, vol I, $p$ 120; D. Jardine, The Mad Mullah of Somaliland, p 91; A. Hamilton, Somaliland, pp 241,247.

6 Bogenoemde naamlys (hierna naamlys 1) van kaptein Walter Bonham dui daarop dat 36 vrywilligers van die Transvaal en 26 van die Oranje-rivier Kolonies gekom het. Daarteenoor dui die bogenoemde naamlys wat die bevelvoerder van die Natal Distrik aan die Sekretaris van die Hoë Kommissaris gestuur het (hierna naamlys 2) die aantal vrywilligers respektiewelik op 35 en 22 aan.

Volgens naamlys 1 het agt vrywilligers van die Kaap en een van Natal by die kontingent aangesluit en ooreenkomstig naamlys 2 het tien vrywilligers van die Kaap en agt van Natal by die kontingent aangesluit.

8 NAB, Pretoria: GOV 629 PS 401, Captain Walter Bonham - The Military Secretary to His Excellency The High Commissioner South Africa, Upper Sheikh, Somaliland, 1 June 1903; Ibid, Commander Natal District - The Secretary to the High Commissioner Pretoria, Head Office Natal District, Pietermaritzburg, 21 July 1903; NAB, Pretoria: GOV 629 PS 401, 858/03/17, Colonel G.G. Walton - The Secretary Colonial Office London SW, York, 10 November 1903.

9 NAB, Pretoria: GOV 629 PS 401, Commander Natal District - The Secretary to the High Commissioner Pretoria, Head Office Natal District, Pietermaritzburg, 21 July 1903; NAB, Pretoria: LTG, Houer 114, Saamgebind met Minute No 155/04, Arthur Elderton - The Military Secretary Pretoria, PO Cristiana, 16 November 1903; Ibid, Lêer 102/3, vol II, (Somaliland Matters, Boer Gratuity), No LC 102/3, Private Secretary Lieutenant-Governor's Office Pretoria - The District Paymaster Army Headquarters SB Pretoria, Pretoria, 6 April 1905. 
Kock "verander" en F. Roux se regte naam was Rowlands. Die Skot Stewart het die naam A. Kraft aangeneem alhoewel laasgenoemde nie ' $n$ tipiese Afrikaanse van is nie. ${ }^{10}$

Die historikus Albert Grundlingh beweer dat 40 lede van die kontingent se Vrystaatse burgers gedurende die Tweede Anglo-Boereoorlog vir Brittanje in die sogenaamde Farmers' Guard geveg het en dat ongeveer 27 Transvaalse burgers van die kontingent of wapenneerlêers - daardie burgers wat voor die beëindiging van die Anglo-Boereoorlog hul wapens neergelê het - was of as National Scouts aan die kant van Brittanje geveg het tydens die AngloBoereoorlog. ${ }^{11}$

Die naamlys wat kaptein Walter F. Bonham van die Essex Regiment in Brittanje, bevelvoerder van die Somaliland Burgher Contingent, oor die lede van die kontingent saamgestel het, lewer die volgende statistieke. Ses van die Boerekrygers in die kontingent het aan die Britte oorgegee voor die beëindiging van die oorlog op 31 Mei 1902. Twee het oorgegee nadat die Britse mag Bloemfontein op 13 Maart 1900 beset het, een het na die val van Johannesburg op 31 Mei 1900 oorgegee, 'n verdere twee het wapen neergelê nadat Pretoria op 5 Junie 1900 ingeneem is en een het te Komati Poort oorgegee. Volgens Bonham se naamlys het slegs twee Boere vir die Britse owerhede gewerk tydens die oorlog nadat hulle oorgegee het. Hendrik L. Laubscher, ' $n$ Transvaalse burger, het as ' $n$ klerk in die kantoor van die Britse Militêre Goewerneur gewerk en die Vrystater George Massyn, het in 'n Britse dierehospitaal gewerk. Die ses lede kan dus as wapenneerlêers of "hensoppers" geklassifiseer word. ${ }^{12}$

Daar is geen bewyse gevind dat enige Boere van die Somaliland Burgher Contingent aan Britse kant gedurende die Anglo-Boereoorlog geveg het nie. Trouens, 25 van die Boere het teen Brittanje geveg, insluitende die ses "hensoppers". Agt van dié stryders is deur die Britte gevange geneem. Drie is as Britse krygsgevangenes na St Helena en twee na
Ceylon gestuur. ${ }^{13}$ Daar was selfs twee "bittereinders" - Boere wat tot en met vredesluiting hulle teen Brittanje verset het - wat by die kontingent aangesluit het. Hulle was E.J. Louw en B. Harres van die Transvaal. Jakob Trotski, ook ' $n$ lid van die kontingent, is ' $n$ baie interessante geval. Hy was ' $n$ Kaapse rebel wat gedurende die Anglo-Boereoorlog aan die kant van die Boere geveg het. ${ }^{14}$

Die Boere wat deel van die kontingent was, sou vir meer as drie maande saam met Britse lede van die kontingent, tot kort tevore nog hulle aartsvyande, diens doen in Somaliland. Vyf Britse soldate het in die kontingent gedien. Drie van hulle, J. Lowie, G. Johnson en $\mathrm{H}$. Halewood, was tydens die AngloBoereoorlog onderskeidelik verbonde aan 13th Hussars, 2nd West Yorkshire Regiment en 17th Lancers. Hulle het egter nie as lede van hierdie regimente in die kontingent diens verrig nie, maar as vrywilligers. Die ander twee soldate, B. Woodhead en E. Adkin, het as lede van 2nd West Yorkshire Regiment spesiale diens in die kontingent verrig. Oudlede van koloniale eenhede wat vir Brittanje geveg het tydens die Anglo-Boereoorlog, het ook by die kontingent aangesluit. John S. Schroeder was lid van die Imperial Light Horse Regiment en Victor Le Gros het diens in die Cape Mounted Riflemen verrig. Beide was Kaapse burgers. ${ }^{15}$

Benewens die professionele soldate in die kontingent het die ander lede ' $n$ wye verskeidenheid siviele beroepe beoefen. Daar was klerke, boere, plaasarbeiders en ambagslui. Laasgenoemde groep het ' $n$ baksteenlêer, ' $n$ skilder en papierhanger, 'n platelêer, 'n slagter, 'n klipmesselaar en timmermanne ingesluit. Spoorwegwerkers, 'n kondukteur, en 'n saagmeularbeider het ook aangesluit. ' $n$ Skotskardrywer, ' $n$ taxibestuurder en ' $n$ invoerder van perde het ook onder die lede van die kontingent getel. Ook lede van die milisiemag, die South African Constabulary het by die kontingent aangesluit. Een lid het vir die Britse leër se arbeidsdepartement gewerk en ' $n$ ander vir die repatriasieraad in Pretoria. ${ }^{16}$ Een vrywilliger was ' $n$ toesighouer oor swartes

10 NAB, Pretoria: GOV 629 PS 401, Captain Walter Bonham -The Military Secretary to His Excellency The High Commissioner South Africa, Upper Sheikh, Somaliland, 1 June 1903.

11 A.M. Grundlingh, Die Vrystaatse en Transvaalse Burgers wat die Republikeinse Oorlogspoging vanaf 1900 versaak het: Hulle rol en posisie gedurende die tydperk 1900-1907(Ongepubliseerde MA-verhandeling, UNISA), p 364; A.M. Grundlingh, Collaborators in Boer Society, in P. Warwick (red) ea, The South African War: The Anglo-Boer War 1899-1902, pp 266-267,269-271. Die Farmers' Guard het uit burgers van die distrik Bloemfontein bestaan wat die Vrystaatse hoofstad en omgewing teen' $n$ Boere-inval moes beskerm. Die National Scouts was 'n korps binne die Britse Leër en het uit Transvaalse Burgers bestaan.

12 NAB, Pretoria: GOV 629 PS 401, Captain Walter Bonham - The Military Secretary to His Excellency The High Commissioner South Africa, Upper Sheikh, Somaliland, 1 June 1903;T. Pakenham, The Boer War, p 581

13 Daar was Britse krygsgevangenekampe op St. Helena, Ceylon, Bermuda en in Indië. C.H. Benbow, Boer Prisoners of War in Bermuda, pp 1-3.

14 NAB, Pretoria: GOV 629 PS 401, Captain Walter Bonham - The Military Secretary to His Excellency The High Commissioner South Africa, Upper Sheikh, Somaliland, 1 June 1903. Kaapse rebelle is deur die Britte as verraaiers beskou aangesien die Kaap Kolonie deel van die Britse Ryk was.

15 NAB, Pretoria: GOV 629 PS 401, Captain Walter Bonham - The Military Secretary to His Excellency The High Commissioner South Africa, Upper Sheikh, Somaliland, 1 June 1903; Ibid, 858/03/17, Colonel G. G. Walton - The Secretary Colonial Office London SW, York, 10 November 1903; I.S. Hallows, Regiments and Corps of the British Army, pp 61,74-75,154-155.

16 Die repatriasierade is deur die Britse regering na die Anglo-Boereoorlog ingestel om ekonomiese hulp en werk aan beide "bittereinders" en "joiners" te verskaf. A.M. Grundlingh, Collaborators in Boer Society, in P. Warwick (red) ea, The South African War, pp 275-276. 
op die myne. ' $n$ Seeman, 'n Bloemfonteinse polisieman, 'n naturellekommissaris van Rhodesië, ' $n$ lyfkneg en ' $n$ diamantprospekteerder het ook aangesluit. Professionele lui, te wete twee mediesepraktisyns, 'n veearts, 'n manlike verpleêr en twee ingenieurs het ook aangesluit. ${ }^{17}$

Die Somaliland Burgher Contingent is deur kaptein Bonham aangevoer. Net na afloop van die AngloBoereoorlog was kaptein Bonham gemoeid met die repatriasie van Boere-krygsgevangenes wat vanaf Britse krygsgevangenekampe in die buiteland, na Suid-Afrika teruggekeer het. Goewerneur Alfred Milner ${ }^{18}$ het Bonham geloof vir sy werk as repatriasie-offisier. Kaptein A. A. McHardy van Edinburg in Skotland en kaptein W.L. Foster was Bonham se tweede in bevel. Die luitenante van die Transvaalse vrywilligers was C.L. Cronje, N.S. lisager en Scott Harden en luitenant C.J. Scott het die vrywilligers van die Oranje-rivier Kolonie aangevoer. J. Stableford van Burmingham in Engeland was die kontingent se dokter. ${ }^{19}$

Die lede van die Somaliland Burgher Contingent was manne van goeie kaliber en Bonham het hulle later soos volg geprys: "The general behaviour of the men, their natural sense of good order and discipline and the cheerfulness with which they have responded whenever called upon have been beyond all praise that I can give." ${ }^{20}$ Bonham het egter bygevoeg dat daar weliswaar ' $n$ paar lede was wat nie tot die kontingent toegelaat moes word nie. Bonham was veral ontevrede oor die groep vrywilligers wat te Christiana deur luitenant Scott Harden gewerf is. Van die dertien vrywilligers wat hier aangesluit het, was Bonham slegs met vier manne tevrede. ${ }^{21}$

\section{Redes waarom vrywilligers by die Somaliland Burgher Contingent aangesluit het}

Die ekonomieë van die twee voormalige Boere Republieke het na afloop van die Anglo-Boereoor- log aan skerwe gelê. Gedurende die oorlog is die hoofsaaklik landelike Boerekrygers se plase deur die Britse soldate vernietig en miljoene skape, beeste en perde het óf weens die oorlog óf weens peste gevrek. Onmiddellik na die oorlog is die reeds kritieke toestand in die twee nuwe kolonies vererger deur 'n droogtetydperk wat in 1902-1903 geheers het, asook die onvrugbare landbougrond van die Transvaal Kolonie en die onwetenskaplike landboumetodes wat deur die Boere gevolg is voor die uitbreek van die Anglo-Boereoorlog. ${ }^{22}$

Brittanje het gepoog om die voormalige republieke te help en in totaal $£ 14500000$ in Suid-Afrika spandeer om die land weer op die been te bring. Die meeste van hierdie geld is gebruik om die Boere wat materiële verliese gely het gedurende die oorlog, te help. Die toekenning van hierdie geld is op 'n onverantwoordelike wyse geadministreer deurdat fondse wat dringend benodig is, of te stadig bewillig is of vir minder belangrike sake aangewend is. ${ }^{23}$

Dit is dus te verstane dat burgers van die Transvaal en Oranje-rivier Kolonies die Somaliland Burgher Contingent as ' $n$ uitkoms uit die uiters ongunstige ekonomiese omstandighede waarin hulle hul bevind het, beskou het.

Die laagste range in die kontingent het ' $n$ soldy van vyf sjielings per dag ontvang, 'n korporaal ses sjielings per dag, sersante sewe sjielings, sersantmajoors agt sjielings en die luitenante en die dokter twintig sjielings per dag. ' $n$ Kaptein se soldy was 21 sjielings per dag. Dit is interessant om daarop te let dat die laagste range in die kontingent dieselfde betaling as hulle eweknieë in die National Scouts gedurende die Anglo-Boereoorlog ontvang het. Daarteenoor het ' $\mathrm{n}$ korporaal in die National Scouts slegs een sjieling en 'n sikspens meer ontvang as ' $\mathrm{n}$ korporaal in die Somaliland Burgher Contingent. Albert Grundlingh verklaar dat hierdie bedrae "...fairly substantial amounts for men in

17 NAB, Pretoria: GOV 629 PS 401, Captain Walter Bonham - The Military Secretary to His Excellency The High Commissioner South Africa, Upper Sheikh, Somaliland, 1 June 1903 [Nie al die lede se beroepe word in dié naamlys aangedui nie]; Ibid, Commander Natal District - The Secretary to the High Commissioner Pretoria, Head Office Natal District, Pietermaritzburg, 21 July 1903.

18 Alfred Milner was vanaf 1897-1905 Britse Hoë Kommissaris vir Suid-Afrika en vanaf 1901-1905 Goewerneur van die Transvaal en Oranje-rivier Kolonies.

19 NAB, Pretoria: GOV, Haven 622, Lêer PS 391, vol I, (Omnium Gatherum Report for 1902 Correspondence), No 141, Governor Milner - The Right Honourable Joseph Chamberlain MP Colonial Office London, Governor's Office Johannesburg, 14 March 1903; NAB, Pretoria: GOV 629 PS 401, Commander Natal District -The Secretary to the High Commissioner Pretoria, Head Office Natal District, Pietermaritzburg, 21 July 1903; NAB, Pretoria: LTG, Houer 114, Lêer 102/3, vol II, (Somaliland Matters, Boer Gratuities), Nominal Roll Somaliland Burgher Contingent.

20 NAB, Pretoria: GOV 629 PS 401, Captain Walter Bonham - The Military Secretary to His Excellency The High Commissioner South Africa, Upper Sheikh, Somaliland, 1 June 1903.

21 NAB, Pretoria: GOV 629 PS 401, Captain Walter Bonham - The Military Secretary to His Excellency The High Commissioner South Africa, Upper Sheikh, Somaliland, 1 June 1903.

22 T. Pakenham, The Boer War, p 572; D. Denoon, A Grand Illusion: The failure of imperial policy in the Transvaal Colony during the period of reconstruction 1900-1905, p 60; S.E. Katzenellenbogen, Reconstruction in the Transvaal, in P. Warwick (red) ea, The South African War, pp 346-347,348.

23 S.E. Katzenellenbogen, Reconstruction in the Transvaal, in P. Warwick (red) ea, The South African War, p 348; D. Denoon, $A$ Grand Illusion, pp 63,65. 
possible need' was gedurende die vroeë jare van die twintigste eeu. ${ }^{24}$

Sommige van die vrywilligers (dertien altesaam) het by die kontingent aangesluit nadat valse beloftes aan hulle gemaak is. Luitenant Scott Harden, die Assistent-Distriksamptenaar van die Repatriasie Departement te Christiana (Transvaal), het aan die vrywilligers belowe dat, benewens die vyf sjielings per dag wat hulle sou ontvang, daar ook ' $n$ bonus van $£ 50$ en 'n plaas na afloop van die dienstydperk van ses maande aan hulle toegeken sou word. Die offisier het egter nie die gesag gehad om sulke beloftes te maak nie aangesien hy dit sonder die medewete of goedkeuring van die Britse regering en die militêre owerhede gedoen het. Hierdie groep vrywilligers het gevolglik nie hierdie beloofde vergoeding na afloop van die veldtog ontvang nie. Vier lede van hierdie groep; G.C. Willey, C. McGonigal, J.K. Trotski en J.F. Few het na die ekspedisie teen die Mullah beweer dat: "The promises of Major Scot Harding [sic] induced us to enlist as we should certainly never have enlisted without these promises." 25

Die uiters ongunstige ekonomiese toestande wat in Suid-Afrika geheers het, kon die lede wat aan Boerekant geveg het tydens die Anglo-Boereoorlog, dus laat besluit het om by die kontingent aan te sluit. Ook die Engelssprekendes, "joiners" en "hensoppers" van die kontingent het waarskynlik so ' $n$ stap as ' $n$ moontlike oplossing vir hul finansiële probleme beskou.

Politieke redes het ook sekere persone aangespoor om by die kontingent aan te sluit. Soos reeds bespreek, was daar sewe lede wat tydens die AngloBoereoorlog aan Britse kant geveg het. Vyf was Britse soldate en twee het in koloniale eenhede gedien. Nasionalisme kon hierdie lede moontlik geïnspireer het om vir Brittanje teen die Mullah te gaan veg. Die ses bogenoemde lede wat aan Boerekant geveg het, maar voor die beëindiging van die oorlog oorgegee het, het ook moontlik weens politieke oorwegings by die kontingent aangesluit.
Boere wat vir Brittanje geveg het of wat vroeg in die oorlog hul wapens neergelê het, is deur hul "bittereinder" volksgenote verag. Selfs die kerke het teen dié burgers gedraai; dermate dat die predikante wat simpatiek gesind was teenoor burgers wat vroeg reeds hul wapens neergelê het, verplig was om uit die bediening te bedank. Die "hensoppers" wat by die kontingent aangesluit het, het dit moontlik gedoen om van die antagonisme van hul mede-burgers te ontvlug. Selfs sommige Britse amptenare soos Goewerneur Alfred Milner het nie ' $n$ hoë dink van dié Boere gehad nie. ${ }^{26}$

Die belofte van avontuur wat ' $n$ ekspedisie in die Horing van Afrika ingehou het, kon moontlik van die lede gelok het om aan te sluit. Baie van die vrywilligers kon ook aangesluit het omdat hulle "beroepsoldate" was. Vyf en twintig was Boerekrygers, sewe was Britse soldate, drie lede het aan die South African Constabulary behoort na afloop van die Anglo-Boereoorlog en een was verbonde aan die polisie in Bloemfontein. ${ }^{27}$ Dit is dus moontlik dat hierdie lede, weens drie jaar se onafgebroke stryd, niks anders kon of wou doen as oorlogmaak nie.

\section{Die totstandkoming van die Somaliland Burgher Contingent}

Die veldtog om lede vir die Somaliland Burgher Contingent te werf, het laat in 1902 begin. Die kontingent sou deel vorm van die Somaliland Field Force. Belangstellendes het aansoek gedoen by die kantore van die Luitenant-Goewerneurs van die Transvaal en Oranje-rivier Kolonies. Dié kantore het hierop vir kaptein Bonham laat weet dat hy met die applikante moes korrespondeer. Kaptein Bonham het die volgende te sê gehad oor die wyse waarop die kontingent op die been gebring is: "Very few days were available for raising the corps, and time did not permit of any enquiries being made into the antecedents or character of persons enlisted." Om hierdie rede, het Bonham verklaar, is 'n paar persone toegelaat wat andersins, afgekeur sou word. 28

24 A.M. Grundlingh, Collaborators in Boer Society, in P. Warwick (red) ea, The South African War, p 269; NAB, Pretoria: GOV 629 PS 401, Captain G.R. Kewick Assistant Military Secretary - The Military Secretary HE The High Commissioner Johannesburg, Head Quarters South Africa, Pretoria, 1 August 1903.

25 NAB, Pretoria: GOV 629 PS 401, Brief: G.C. Willey ea - The Military Secretary Johannesburg, Christiana Transvaal, 27 August 1903; Ibid, Brief: Major F.J. Henley - G.C. Willey ao Christiana (Transvaal), High Commissioner's Office Johannesburg, 1 September 1903; NAB, Pretoria: GOV 629 PS 401, NO M S /588/03, High Commissioners Office - Messrs Evans \& Mynhardt Christiana, Johannesburg, 29 October 1903.

26 NAB, Pretoria: GOV 629 PS 401, Captain Walter Bonham - The Military Secretary to His Excellency The High Commissioner South Africa, Upper Sheikh, Somaliland, 1 June 1903; A.M. Grundlingh, Collaborators in Boer Society, in P. Warwick (red) ea, The South African War, pp 276-277; A.M. Grundlingh, Die Vrystaatse en Transvaalse Burgers (Ongepubliseerde MA-verhandeling, UNISA), pp 354-355.

27 NAB, Pretoria: GOV 629 PS 401, Captain Walter Bonham - The Military Secretary to His Excellency The High Commissioner South Africa, Upper Sheikh, Somaliland, 1 June 1903.

28 NAB, Pretoria: GOV 629 PS 401, Captain Walter Bonham - The Military Secretary to His Excellency The High Commissioner South Africa, Upper Sheikh, Somaliland, 1 June 1903; NAB, Pretoria: LTG, Houer 114, Lêer 102/6, (R.H. Chase re services for Somaliland), LG 1581 R.H. Chase: Re services for Somaliland, Lieutenant-Governor's Office - Captain Bonham Pretoria, 8 January 1903, Private Secretary. 
Reeds op 4 November 1902 het die koerant De Zuid-Afrikaan berig dat die nuus dat Boere vir militêre diens in Somaliland aansoek gedoen het, met "verwondering en tevredenheid" in Londen ontvang is. ${ }^{29}$ Op 8 November 1902 het dieselfde koerant berig dat die Militêre Sekretaris van Goewerneur Alfred Milner, opdrag gegee het dat geen nuwe rekrute vir diens in Somaliland opgeneem moes word nie. Die Britse ministerie van buitelandse sake het moontlik Milner hierdie opdrag gegee nadat voldoende rekrute gewerf is. ${ }^{30}$

Op 6 Januarie 1903 is I.R. Walsh, die stafoffisier verantwoordelik vir Boere-krygsgevangenes in Kaapstad, deur die hoofprovoos (Provost Marshal) in Pretoria opdrag gegee om vas te stel of enige van die Boere-krygsgevangenes aan boord van die skip SS Dunera, wat na Suid-Afrika teruggekeer het vanaf Britse krygsgevangenekampe in die buiteland, nie by die Somaliland Burgher Contingent wou aansluit nie. Nie een van hierdie Boere was egter bereid om vir hul eertydse vyand militêre diens te verrig nie. ${ }^{31}$

Kolonel R.S.S. Baden-Powell, die InspekteurGeneraal van die South African Constabulary, is deur Goewerneur Alfred Milner op 7 Januarie 1903 in kennis gestel dat al die burgers wat aan hierdie milisie-eenheid behoort, toegelaat sou word om by die Burgher Contingent aan te sluit. Aanvanklik is slegs 50 lede van die South African Constabulary toegelaat om by die kontingent aan te sluit. Veral majoor E.M.H. Leggett, die Algemene Stafoffisier van die National Scouts tydens die AngloBoereoorlog, was gretig dat Afrikaanssprekendes in die South African Constabulary by die Burgher Contingent moes aansluit aangesien hulle volgens hom ' $n$ aanwins vir die kontingent sou wees. Baie van die Afrikaanssprekende lede van die South African Constabulary was deel van die National Scouts gedurende die Anglo-Boereoorlog. BadenPowell was teen hierdie besluit gekant aangesien daar baie moeite gedoen is om die rekrute van die South African Constabulary te werf en op te lei. Die South African Constabulary het ook belangrike polisietake verrig soos die opspoor van gesteelde vee. Voorts het Baden-Powell dit as onregverdig beskou dat slegs die burgers van die South African Constabulary by die kontingent kon aansluit en nie die ander lede nie. Die Inspekteur-Generaal het voorgestel dat, aangesien die South African Constabulary te veel lede gehad het, hy wel vrywilligers sou toelaat om by die Burgher Contingent aan te sluit. Maar hierdie vrywilligers moes nie burgers wees nie maar ander lede van die South African Constabulary soos Kanadese, wat nie doeltreffend binne dié milisie-eenheid aangewend kon word nie. Baden-Powell het egter toegegee en sy manne laat weet dat, indien hulle by die Burgher Contingent wou aansluit, hulle na afloop van die ekspedisie teen die Mullah weer in die geledere van die South African Constabulary opgeneem sou word. ${ }^{32}$

Nieteenstaande dié maatreëls van die Britse owerhede het slegs drie lede van die South African Constabulary by die Burgher Contingent aangesluit en twee het Afrikaanse vanne gehad. ${ }^{33}$

Die werwing van rekrute het op 15 Januarie 1903 tot ' $n$ einde gekom toe die Somaliland Burgher Contingent Suid-Afrika verlaat het. In April 1903 het lede van die Johannesburg Mounted Rifles asook ander vrywilligers aangebied om in Somaliland te gaan veg. Die Britse regering in Londen het egter in Mei 1903 verklaar dat die Somaliland Field Force, waarvan die Somaliland Burgher Contingent' $\mathrm{n}$ deel was soos voorheen reeds genoem, geen nuwe rekrute kon neem nie omdat die mag nie oor genoegsame ry- en pakdiere in Somaliland beskik het nie. ${ }^{34}$

Op 15 Januarie 1903 het die Somaliland Burgher Contingent saam met ' $n$ kompanie British Mounted

29 NAB, Pretoria: Mikrofilm CL 364 m 2215, Deel 74 no 7231, De Zuid-Afrikaan, Zaterdag 4 November 1902, Kaapstad

30 NAB, Pretoria: Mikrofilm CL 364 m 2215, Deel 74 no 7233, De Zuid-Afrikaan, Zaterdag 8 November 1902, Kaapstad, p 4; Official History, vol I, p 118.

31 NAB, Pretoria: Argiewe van die Stafoffisier, Krygsgevangenes, Kaapstad 1900-1903 (hierna SOPOW), Houer 63, Lêer PR A6013, (Re POW on SS Dunera with Commando in Somaliland), Provost Marshal - Staff Officer, Prisoners of War Cape Town The Castle Cape Town, 6 January 1903; Ibid, RTO The Castle, Cape Town, 6 January 1903, LT for Staff Officer, Prisoners of War

32 NAB, Pretoria: Argiewe van die Hoë Kommissaris 1890-1925 (hierna HC), Houer 2, Lêer 45, SAC (Various 1 Jan 1902 - March 1903), Ex A 100/11/2A, Brief: Baden-Powell - Henley, 8 January 1903; Ibid, Brief: Baden-Powell - Lembton, 6 Januarie 1903; Ibid, Brief: E.M.H. Leggett - Colonel, Office of the Director Burgher Land Settlement Visagie Street Pretoria, 19 December 1902; D. Denoon, A Grand Illusion, p 49; A.M. Grundlingh, Collaborators in Boer Society, in P. Warwick (red) ea, The South African War, p 269 .

33 NAB, Pretoria: GOV 629 PS 401, Captain Walter Bonham - The Military Secretary to His Excellency The High Commissioner South Africa, Upper Sheikh, Somaliland, 1 June 1903

${ }_{34}$ NAB, Pretoria: HC, Houer 66, Lêer 121 1A, (Volunteer Contingent for Somaliland), Telegram no 2: Governor Johannesburg Secretary of State London, 30 April 1903; Ibid, Copy 5/23/11, RPS 401, Decode Telegram AH no 1: Secretary of State London Governor Johannesburg, 14 May 1903; Ibid, Telegram no 2: Secretary of State - Governor, 5 May 1903; NAB, Pretoria: LTG Houer 114, Lêer 102/4, (Recruiting for Somaliland), no 4: Assistant Military Secretary - Lieutenant Governor's Office HEThe Lieutenant Governor, 8 March 1903. 
Infantry (141 man sterk) van die King's Royal Rifle Corps Durban op die stoomskip SS Gaul verlaat ${ }^{35}$. hul bestemming: Somaliland. ${ }^{36}$

\section{Mohammed Abdulle Hassan en sy volgelinge}

Die opkoms van Mohammed Abdulle Hassan (die Mullah) in Somaliland, wat tot die stryd met Brittanje aanleiding gegee het, moet binne die konteks van die politieke en religieuse milieu in Somaliland gedurende die tweede helfte van die 19de eeu verstaan word.

Vanaf die tiende eeu ná Christus het die Moslemgeloof vanaf die Arabiese en Persiese kussentra soos Zeila en Mogadishu deur Noordoos-Afrika versprei. Die Moslem-geloof het in Somaliland floreer sodat daar teen die einde van die 19de eeu drie Moslem-broederskappe of Ordes hier aanwesig was: die Qadiriyya-, Ahmadiyya- en Salihiyya-broederskappe. Eersgenoemde twee broederskappe of tariqas het die Sufi of mistieke siening van die Moslem-geloof uitgedruk wat onder andere die verheerliking van die charismatiese magte van die heiliges ingesluit het. Verder het die broederskappe godsdienstige waardes bevorder deur middel van ' $n$ eie unieke liturgie. Gedurende die 19de eeu het lidmaatskap aan 'n broederskap sinoniem geraak met die Somaliese geloofsbeskouing en godsdiensbeoefening. ${ }^{37}$

Die Mullah het aan die Salihiyya-broederskap behoort wat die jongste en radikaalste van die drie was. Hierdie beweging is sterk beïnvloed deur die Al-Wahhab faksie wat alle vernuwings in die Moslem-geloof wat ouer as die 3de eeu van Islam was - soos die geloof in die tussenkoms van Mohammed, sy metgeselle of die Sufi-heiliges vir die individu - wou vernietig. Nog ' $n$ kenmerk van dié faksie is dat dit anti-Westers was. Laasgenoemde was 'n reaksie op die Westerse koloniale indringing in Afrika en Asië gedurende die tweede helfte van die 19de eeu. Somaliland is deur Brittanje, Italië en Frankryk bedreig en omrede dié onderdrukkers ook Christene was, het die anti-Westerse houding gelei tot sterk vyandigheid jeens die Christendom. ${ }^{38}$

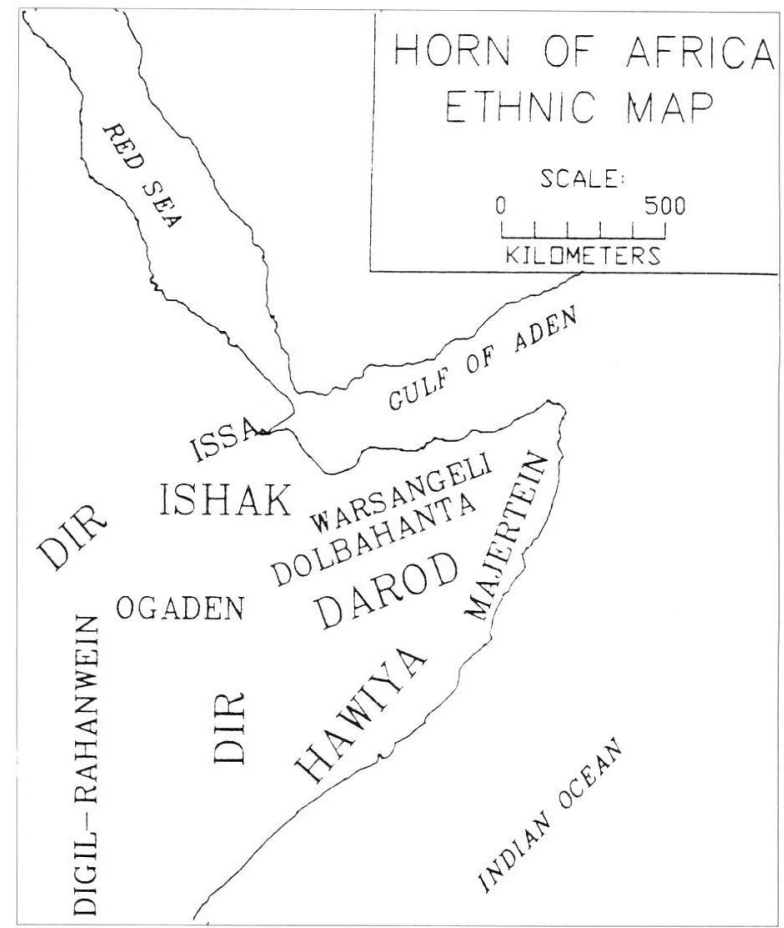

'n Etniese kaart van Somaliland, ca 1900

A. Sheik - Abdi, Divine Madness : Mohammed Abdulle Hassan (1856-1920), London, 1993, p 22

Die Mullah was, net soos sy geestelike voorgangers, ook hewig teen enige vernuwing in die Moslem-geloof gekant en was anti-Westers gesind. Nadat hy tussen 1890 en 1895 vanaf Arabië teruggekeer het - waar hy deur die stigter van die Salihiyya-broederskap, Sheikh Muhammad Salih van Mekka, onderrig is - het hy die Somaliërs aangemoedig om hulle by die strenger voorskrifte van die Salihiyya-broederskap neer te lê. Die Mullah het ' $n$ godsdienstige sentrum of jama'a te Berbera aan die noordkus van die Britse Protektoraat gevestig en hier het hy sy asketiese en anti-Westerse Wahhabiyya-Salihiyya doktrines verkondig as " $n$ khalifa of verteenwoordiger van Sheikh Salih. ${ }^{39}$

Die Mullah se voorskrifte aan sy volksgenote het onder andere die nakoming van die uur van gebed en die verbanning van sekere populêre bygelowe, soos die geloof in die tussenkoms van die heiliges, ingesluit. Hy het sy landgenote, wat ooreenkomstig die gebruike en beginsels van die Christendom gelewe het, sterk veroordeel. Hy het sy aanval

35 NAB, Pretoria: LTG, Houer 114, Lêer 102/3, vol I, (Capt Scott Hardin War Gratuity-Somaliland), W. Bonham Captain Essex Regiment Commanding Burgher Contingent, Galkayu Wells, Somaliland, 24 March 1903, A 3133/22, Lt Col AAG for CSO C.M. McGrigor, The CSO AHQ Pretoria - CP Cape Town, Pretoria, 5 June 1903; Official History, vol I, p 120; NAB, Pretoria: Mikrofilm CL 364 m 2215, Deel 75 no 7263, De Zuid-Afrikaan, Zaterdag 17 Januari 1903, Kaapstad, p 5.

36 Somaliland lê in die Horing van Afrika aan die ooste en noordooste van Ethiopië. Die Somaliërs is van Hamitiese afkoms en is in vier klan-families georganiseer: die Dir, Isaq, Hawiye en Darod. Patriliniêre verwantskap vorm die basis van die Somaliërs se sosiale organisasie en die mees aktiewe en bindende organisasie is die sogenaamde diya-betaalgroep. Lewis verklaar dat hierdie organisasie: "...consists of close kinsmen united by a specific contractual alliance whose terms stipulate that they should pay and receive blood-compensation (Arabic, diya) in concert." Die Moslem-geloof word in Somaliland aangehang. Die Somaliërs was en is hoofsaaklik pastorale-nomade, dit wil sê hulle is veeboere wat saam met hul vee deur Somalië rondtrek op soek na weiding. I.M. Lewis, The Modern History of Somaliland: From Nation to State, pp 6,7,10,11,12,19.

I.M. Lewis, The Modern History of Somaliland, pp 20-22,63-65.

38 A. Sheik-Abdi, Divine Madness, pp 56-58; I.M Lewis, History of Somaliland, pp 64-65

39 A. Sheik-Abdi, Divine Madness, pp 47-48,56. 
veral teen die handelaars van Berbera, wat luukse Westerse goedere ingevoer het en reeds deur die Westerse beskawing beïnvloed is, gerig. ${ }^{40}$

By geleentheid het die Mullah verklaar dat hy ' $n$ heilige vegter of mujahid was en geen aspirasies gekoester het om roem of mag op aarde te bekom nie. Maar hierdie stelling van die Mullah is nie heeltemal juis nie. Die oorlog teen Brittanje was nie uitsluitlik ' $n$ jihad of heilige oorlog teen die Christene nie maar ook ' $n$ nasionalistiese stryd waartydens die Mullah gepoog het om sy mense van die Britse juk te bevry. In briewe aan die Britte, Italianers en Abessiniërs het hy verklaar dat sy strewe slegs was: om sy mense te regeer, ' $n$ toegang tot die see te bekom, ' $n$ stad vir sy volgelinge te bou en om in vrede te lewe. Die feit dat hy met sy Christen-vyande onderhandel het en met hulle verdrae gesluit het om sy volgelinge se posisie te versterk, wys verder daarop dat die Mullah nie uitsluitlik ' $n$ mujahid was nie maar ook 'n nasionalis. Abdi Sheik-Abdi verklaar: "...Mohammed 'Abdulle Hassan may rightly be regarded as a nationalist on the basis of his lengthy and determined resistance to colonial rule, on his ability to define his people's cause, and finally on the clear link with later nationalists that he represents." ${ }^{41}$

Die Somaliland Burgher Contingent het dus te doen gekry met ' $n$ politieke en godsdienstige vryheidsvegter wat vasberade was om sy mense van die Britse owerhede te bevry.

In die stryd teen Brittanje het die Mullah op sy Derwisj-volgelinge ${ }^{42}$ gesteun. Die Mullah was die onteenseglike leier van dié organisasie en sy volgelinge moes trou aan hom en aan Sheikh Salih sweer. Die Salihiyya-broederskap was die amptelike godsdiens van die beweging. ' $n$ Raad het oor staatsake besluit en die lyfwag van die Mullah moes die leier en die hoofstad beskerm. ${ }^{43}$

Die Derwisj-leër (marra-weyn) het uit sewe regimente - elk gemiddeld 2000 man sterk - bestaan. Elke regiment het ' $n$ militêre goewerneur as aanvoerder gehad wat deur die Mullah self aangewys is. Tydens die Derde Ekspedisie het die Mullah se leër aangegroei tot tussen 23500 en 24500 man, wat 2500 soldate met gewere, 5000 tot 6000 berede troepe en 16000 spiesdraers ingesluit het. Elke regiment het sy eie kwartiere, perde en wapens gehad. Die Mullah het onder andere die Gras, Lebel en Martini-Henry-gewere vir sy krygers ingevoer.
Benewens die gewere wat die Derwisje gebruik het, is swaarde, skilde, spiese en soms pyl-en-boë, messe en slingervelle in die stryd aangewend. ${ }^{44}$

Laastens was daar die gewone volgelinge of reerbeede. Die Mullah se eerste volgelinge was die Ali Gheri, sy moedersmense. Laasgenoemde was deel van die Dolbahanta-stam en die grootste getal van die Derwisj-beweging se volgelinge was uit die stam afkomstig. Die hele Ogaden-stam - die stam waaraan die Mullah behoort het - het moontlik aan die Derwisj-beweging behoort voordat oorlog met Brittanje uitgebreek het. ${ }^{45}$

Die Somaliërs het nie verenig agter die Mullah gestaan nie. Hulle was van nature uiters individualisties en die gemeenskap is verder deur twiste en onenigheid uitmekaar geskeur. Sekere klans en linies het gepoog om die Europese en Abessiniese intriges in hul land tot hul eie voordeel uit te buit deur die imperialiste teen mekaar af te speel. Dit het die posisie van die Somaliërs verswak en die Europeërs aangemoedig om hul belange in die gebied uit te brei. Verder was die inwoners van Berbera die Mullah vyandiggesind omdat hy hul verbintenisse met die Engelse afgekeur het en hy aan die Ogaden-stam behoort het. Laasgenoemde stam en die inwoners van Berbera het nie op goeie voet met mekaar verkeer nie aangesien die Ogaden-stam hulle daarvan beskuldig het dat hulle hul besittings geplunder het wanneer hulle die stad besoek en omdat hulle belasting hier moes betaal om hul goedere te kon verkoop. Die Ishak-stamme van die Britse Protektoraat is gedurende 1899 en 1900 deur die Mullah aangeval. Ook die Dolbahanta is deur die Mullah aangeval aangesien van hulle geweier het om by sy beweging aan te sluit. Verder het die suidelike deel van die Somaliese gebied die Qadiriyya-broederskap aangehang wat antagonisties teenoor die meer radikale Salihiyya-broederskap gesind was. Selfs van die Mullah se lojale Ogaden-onderdane het by geleentheid sonder sukses gepoog om sy bewind omver te werp. ${ }^{46}$

Die Mullah het grootliks daarin geslaag om die individualistiese aard van sy volgelinge te bekamp deur streng dissipline toe te pas. Oortreders is om die lewe gebring vir die geringste oortreding en geen onderskeid is gemaak op grond van die oortreder se posisie in die samelewing nie. Daar was ook ander faktore wat die Derwisje verenig het. Die Mullah: "...provided structure and inspired leadership to a society that was in dire need of both." 47

\footnotetext{
40 A. Sheik-Abdi, Divine Madness, pp 58-60.

41 A. Sheik-Abdi, Divine Madness, pp 54-55,58,207,211.

42 Die letterlike betekenis van Derwisje is Mohammedaanse bedelmonnike.

43 A. Sheik-Abdi, Divine Madness, pp 195-196,202.

44 A. Sheik-Abdi, Divine Madness, p 196; Official History, vol I, pp 146,320-321.

45 A. Sheik-Abdi, Divine Madness, pp 51,100,101,105,196.

46 A. Sheik-Abdi, Divine Madness, pp 60,93,98,102,105,204; I.M. Lewis, History of Somaliland, pp 43,57.

47 A. Sheik-Abdi, Divine Madness, pp 196,204,205.
} 
Omdat die Mullah oorlog gemaak het teen die Christene - die Abessiniërs en Engelse - het hy die reputasie van ' $n$ heilige Moslem-kryger verwerf. Hierdie reputasie het daartoe bygedra dat die Mullah nuwe volgelinge gewerf het. Die Mullah het ook vir die behoud van die Somaliese kultuur gestry wat deur die Christendom bedreig is en het ' $n$ verenigde front vir hierdie stryd verteenwoordig. Verder was hy in staat om verskillende broederskappe en gemeenskappe of stamme teen 'n gemeenskaplike vyand te verenig. Die Mullah het ook beskerming aan sy volgelinge gebied in onsekere tye. So het die Somaliese gebruik van stamoorlogvoering en vendettas sy volgelinge nie geraak nie. Daar was gewoonlik ook genoeg voedsel vir sy volgelinge. Daarteenoor is sekere faksies van die Ogaden en Dolbahantastamgroepe gedwing om by hom aan te sluit. Sekere volgelinge het egter minder suiwere motiewe gehad toe hulle aangesluit het: die begeerte om die rykdom van vyandiggesinde stamme te plunder. $^{48}$

\section{Redes vir die uitbreek van vyandighede tussen Brittanje en die Derwisje}

Die Europese indringing in die kusgebied van OosAfrika is een van die hoofredes vir die uitbreek van vyandighede tussen die Derwisje en Brittanje. Gedurende die tweede helfte van die 19de eeu het Brittanje, Frankryk, Italië en Abessinië meegeding om grondgebied in die Horing van Afrika maar dit was hoofsaaklik Britse en Abessiniese teenwoordigheid in hierdie streek, wat tot oorlog sou lei. ${ }^{49}$

Brittanje se belangstelling in die Somaliese gebied het in 1839 ' $n$ aanvang geneem toe Brittanje Aden as ' $n$ halfwegstasie op die kortroete na Indië verower het. Om die garnisoen in Aden van vleis te voorsien en om die handelsroetes in die Somaliese gebied te beveilig, het Brittanje in 1884 handelsverdrae met die vyf noordelike Somaliese klans gesluit: die 'Ise, Gadabursi, Habar Garhajis, Habar Awal en Habar Tol Ja'lo. Ingevolge dié verdrae sou Brittanje vir die beskerming van die klans se onafhanklikheid en vir die behoud van orde in die gebied verantwoordelik wees. Die klans het onderneem om nie ' $n$ derde party in die gebied toe te laat nie. Brittanje is toegelaat om agente in die Somaliese kusgebied aan te stel en gevolglik is Britse Vise-Konsuls of agente te Berbera, Bulhar en Zeila aangestel om die vrede hier te bewaar. Brittanje wou egter so min moontlik verantwoordelikheid in die gebied aanvaar en was slegs gretig

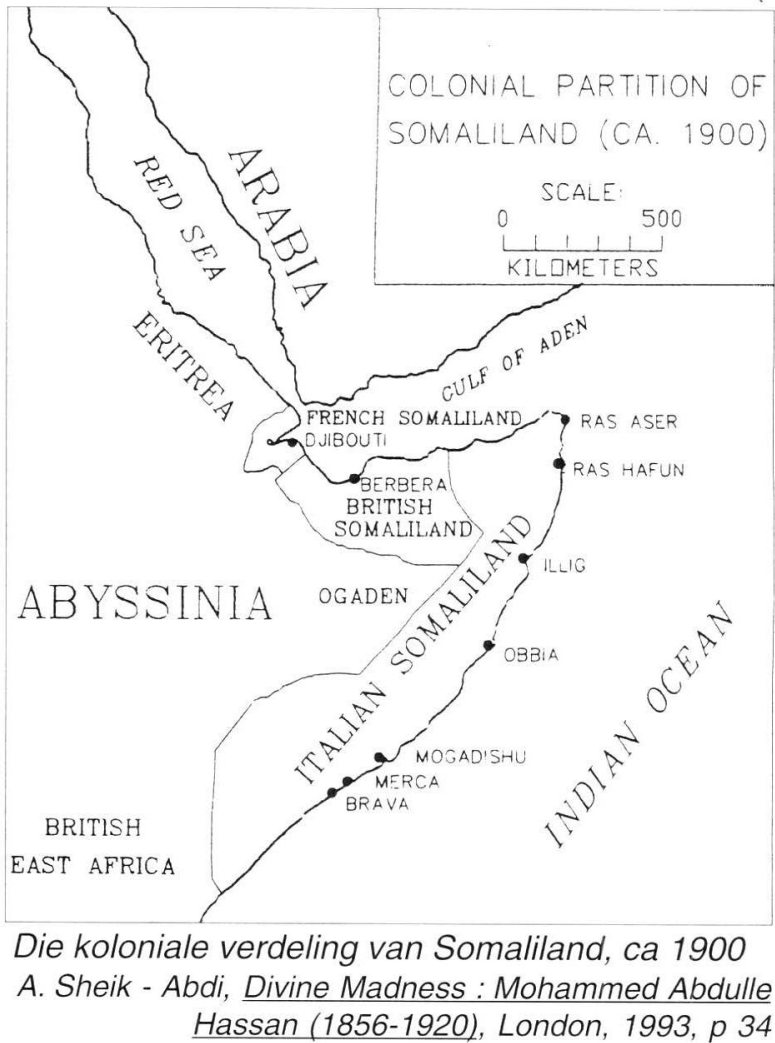

om die noordelike Somaliese kus as ' $n$ bron van voedsel vir die Adense garnisoen te benut. In 1886 het ' $n$ aanvullende verdrag die 1884-verdrag bekragtig en gedurende die volgende jaar het die Somalilandse Protektoraat tot stand gekom. ${ }^{50}$

In 1888 het Brittanje en Frankryk - wat die nedersetting te Jibuti beheer het - 'n ooreenkoms aangegaan waartydens daar besluit is dat die grens van die Britse en Franse invloedsfere tussen Zeila en Jibuti sou loop. Brittanje het in die proses die 1884-verdrag van beskerming met die 'Ise-klan verbreek aangesien laasgenoemde se grondgebied deur hierdie ooreenkoms verdeel is. Ses jaar later het 'n Anglo-Italiaanse protokol tot stand gekom wat dié moondhede se invloedsfere in Somaliland vasgestel het. Daar is ooreengekom dat die Ogaden in die Italiaanse invloedsfeer en die Haud in die Britse invloedsfeer val. Teen 1894 het Italië reeds ' $n$ houvas gehad op die Somaliese Indiese Oseaankus wat die Majerteyn en Benadir streke ingesluit het. Gedurende die daaropvolgende jaar het Brittanje sy gesag na die Somaliese ooskus uitgebrei deur Jubaland as ' $n$ kolonie in te palm en by die British East Africa Protectorate in te lyf. ${ }^{51}$

In 1897 het Brittanje sy Somalilandse Protektoraat verklein deur die Abessiniërs toe te laat om hul gesag in ' $n$ gebied wat ongeveer 107803 vierkante

\footnotetext{
A. Sheik-Abdi, Divine Madness, pp 98,99,196, 205

I.M. Lewis, History of Somaliland, p 40.

I.M. Lewis, History of Somaliland, pp 41,46-47.

I.M. Lewis, History of Somaliland, pp 49,51,52,55-56.
} 
kilometer in die Haud beslaan het en wat vroeër onder Britse beskerming geval het, uit te brei. Brittanje het gevolglik nie sy verdrae met die Somaliërs in die gebied gestand gedoen nie aangesien die Abessiniërs nou toegelaat is om hierdie gebied binne te dring. Laasgenoemde stap was in pas met Brittanje se beleid van beperkte betrokkenheid in die Protektoraat. Omrede baie Somaliërs van die noordelike streke van die Britse Protektoraat na die meer vrugbare sentrale gebiede van die Haud beweeg het, is meer Somaliërs nou aan Abessiniese agressie uitgelewer. Keiser Menelik van Abessinië het reeds gedurende die vorige dekade sekere onafhanklike Somaliese klans in sy gebied geïnkorporeer terwyl die Abessiniese bewindhebber van Harar, Ras Makonnen, Somaliese grondgebied na 1887 binnegeval het. Dorpe en godsdienstige nedersettings is verwoes en vee is gebuit. Gedurende die 1890's het die Somaliërs voortgesette druk op hul noordelike en westelike grense ervaar. Ook Frankryk het die Abessiniërs bevoordeel deur grondgebied prys te gee in ruil vir kommersiële toegewings. ${ }^{52}$

Die Britse regering van Indië, wat die Somalilandse Protektoraat geadministreer het, het probleme met die Somaliërs voorspel aangesien laasgenoemde nie geken is toe die 1897-ooreenkoms met Abessinië gesluit is nie. Hierdie voorspelling sou blyk juis te wees. ${ }^{53}$

Militêre imperialisme het ook tot religieuse imperialisme aanleiding gegee. ' $n$ Franse Roomskatolieke orde het tehuise vir Somaliese wesies op die noordelike Somaliese kus gevestig. Die Mullah het die instansies as ' $n$ bedreiging vir die kultuur en godsdiens van die Somaliërs beskou. Harar, " $n$ heilige stad vir die Moslems, is juis in 1887 deur Abessinië, ' $n$ Christen-land verower met behulp van wapens wat van ander Christen-lande verkry is. ${ }^{54}$

Die Mullah se dade van agressie in Somaliland was nog ' $n$ rede vir die uitbreek van die oorlog. Die Britse Konsul-Generaal in Somaliland, J. Hayes Sadler, het in April en September 1899 berig dat die Mullah die suidoostelike deel van die Protektoraat, Abessinië en Berbera bedreig het. Die trant en inhoud van die Mullah se korrespondensie met die Britse owerhede het laasgenoemde oortuig dat die Mullah op die oorlogspad was. Aan die begin van 1899 is die nedersettings van die Habr Yonis Ishak-klan, wat onder Britse beskerming gestaan het, deur die
Derwisje geplunder. Die Mahmud Gerad-klan van die Dolbahanta-stam, wat nie 'n verdrag met die Britse regering gesluit het nie, is deur die Mullah gedwing om by sy volgelinge aan te sluit. Die Qadiriyya- en Ahmadiyya-gemeenskappe te Sheikh en Hargeisa binne die Britse Protektoraat is deur die Derwisje aangeval. In Augustus 1899 is die Habr Yonis en Dolbahanta-faksies deur die Mullah gestraf omdat hulle afvallig geraak het en Burao is deur die Mullah herbeset. In Oktober van dieselfde jaar is die stamhoof van die Dolbahanta-stam vermoor omdat hy nie die Mullah wou steun nie. Die suidelike en oostelike Ishak - die Ogaden se aartsvyande - is gedurende die laaste helfte van 1899 en dwarsdeur 1900 deur die Mullah aangeval. Een van die Ishak-stamme, die Aidagalla, is swaar gestraf en baie van hul vee is gebuit, toe hulle geweier het om die Mullah in sy stryd by te staan. Die Mullah het ook die Ishak voortdurend weens hul teenstand teen hom in Berbera, aangeval. Die Ishak en ander stamme wat onder Britse beskerming gestaan het, was verplig om die Haud te verlaat weens die Mullah se dade van agressie. Hul vertroue in die Britse bewindhebbers se vermoë om hulle te beskerm, is hierdeur geskud..$^{55}$

Die Mullah het sy aanvalle op sy mede-Moslems en neutrale volksgenote geregverdig deur te verklaar dat die Somaliërs wat hulle by die Christene geskaar het, soos ongelowiges behandel moes word. ${ }^{56}$

Neutrale Somaliese stamme is egter ook deur die Britse bewindhebbers onderdruk. Luitenant-kolonel E.J.E. Swayne het duisende kamele van die Somaliërs vir militêre doeleindes gekonfiskeer. So is die Rer Hared, 'n klan van die Ishak, se vee deur die Britte gekonfiskeer en verkoop. ${ }^{57}$

Die Abessiniërs was ook angstig oor die opkoms van die Mullah. Dit is moontlik dat die Mullah hulle herinner het aan Mohammed Ahmad - die Mahdi van die Soedan - wat ook die "ware" Islam geloof aan sy volgelinge verkondig het. Hy wou ook die vreemde oorheersers van die Soedan, die Egiptenare, uitdryf. In 1883 is die Egiptenare deur die Mahdiste verslaan en Brittanje, wat Egipte in 1882 beset het, het besluit om alle Egiptiese troepe en amptenare uit die Soedan te onttrek. Hierdie oorlog het tot gevolg gehad dat die Abessiniërs grondgebied verloor het en hulle het gevrees dat 'n soortgelyke verloop van gebeure in Somaliland kon volg. ${ }^{58}$

\footnotetext{
I.M. Lewis, History of Somaliland, pp 36,50,57-61,62.

I.M. Lewis, History of Somaliland, p 61.

A. Sheik-Abdi, Divine Madness, pp 36-37,202.

A. Sheik-Abdi, Divine Madness, pp 61-63,92-93,97-99,100,105,106; I.M. Lewis, History of Somaliland, p 50.

A. Sheik-Abdi, Divine Madness, p 106.

A. Sheik-Abdi, Divine Madness, p 37,107.

58 K. Smith en F.J. Nöthling, Afrika noord van die Limpopo: Die imperiale wedervaringe sedert 1800, pp 110-111; A. Sheik-Abdi, Divine Madness, p 95.
} 


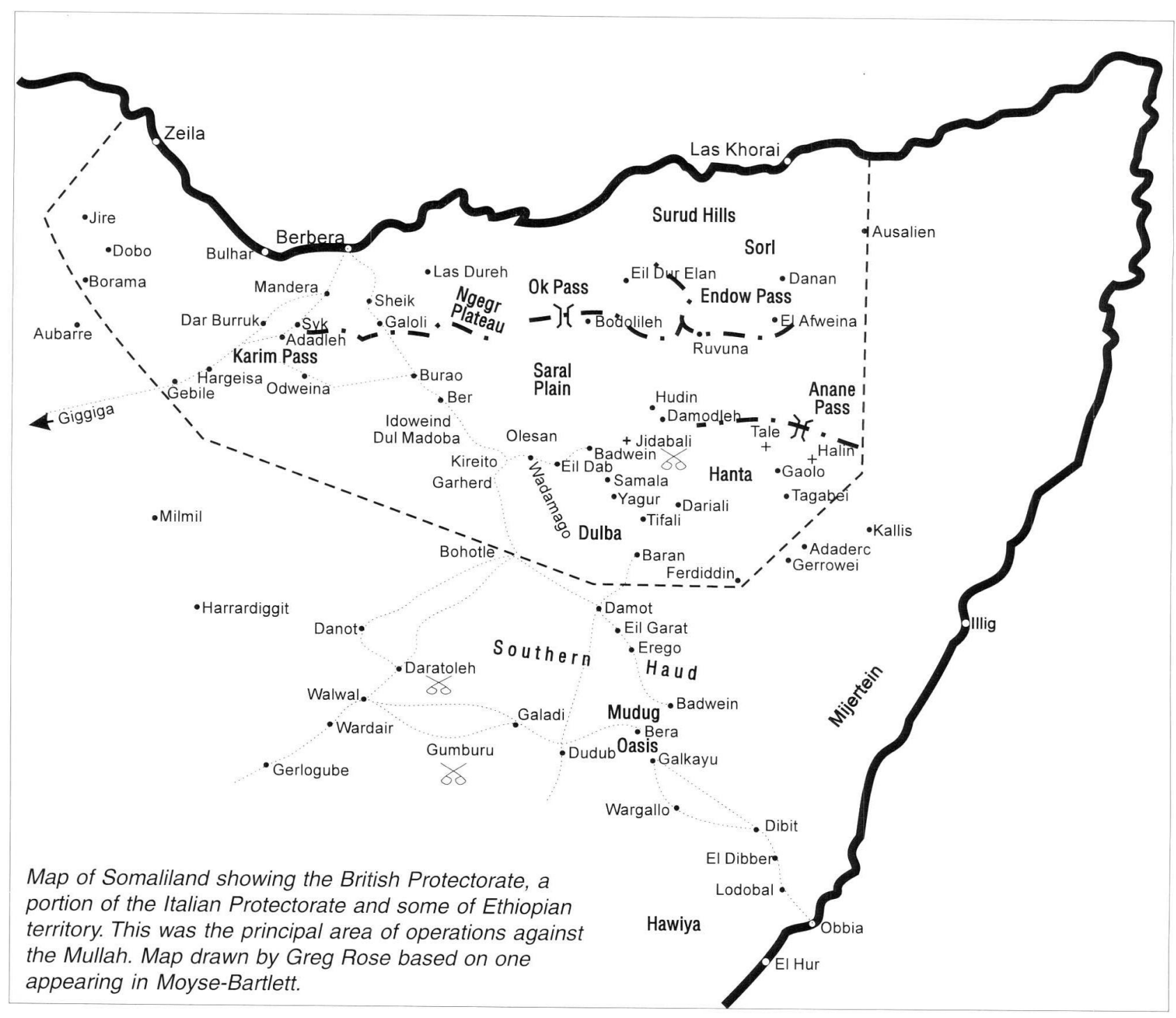

Die area in Somaliland waarin die militêre operasies geloods is. Die stippellyn dui die grense van die Britse Protektoraat aan

L. Bodin, The Mad Mullah of Somaliland, Part 1: Introduction, the First and Second Expeditions, Soldiers of the Queen 24, Feb 1981, p 10

\section{Die Eerste en Tweede Ekspedisies teen die Mullah}

Daar is verskeie redes waarom Brittanje nie reeds gedurende 1899 en 1900 ' $n$ veldtog teen die Mullah geloods het nie. Die Anglo-Boereoorlog en die veldtogte in Jubaland het gedurende hierdie tydperk al Brittanje se aandag geverg. Daarteenoor was die Mullah ook nie oorhaastig om die Britse owerhede in Somaliland aan te val nie. Verder was die Italianers nie baie gretig om die Britte te steun in ' $n$ oorlog teen die Mullah nie omdat hulle self bulle hande vol gehad het met 'n opstand in die Benadir. Ook die Franse wou nie hulp aan hulle koloniale mededinger verleen nie. Die Abessiniërs het die Europeërs gewantrou en moes eers deur Brittanje omgekoop word om hul samewerking te verkry.
Keiser Menelik se imperialistiese oogmerke in die Ogaden en die Mullah se aanval op die Abessiniese stad, Jigjiga, was verdere redes wat die Abessiniërs laat besluit het om hul steun aan Brittanje toe te sê. ${ }^{59}$

Teen November 1900 het die Abessiniërs en Britte besluit dat 'n gesamentlike aanval op die Mullah gedurende April 1901 geloods sou word. Luitenantkolonel E.J.E. Swayne het die eerste twee veldtogte teen die Mullah aangevoer. Die Abessiniërs het stelling ingeneem op die westelike randgebied van die Haud en verhoed dat die Mullah weswaarts kon uitwyk. Tydens die Eerste Ekspedisie is die Mullah twee keer verslaan, eers te Samala gedurende 2-3 Junie 1901 en toe by Ferdiddin op 17 Julie 1901. Die Mullah se mag is egter nie gebreek nie en gevolglik is ' $n$ Tweede Ekspedisie teen hom geloods. 
Tydens dié veldtog het die Italiaanse owerhede die Britte gehelp om wapens, wat na die Mullah op pad was, te onderskep. Vanaf 25 Junie tot 20 Augustus 1902 het die Britse magte wat uit Somaliërs, Indiese troepe en die King's African Rifles bestaan het, strooptogte in die suidoostelike dele van die Protektoraat uitgevoer. Baie volgelinge van die Mullah is gedood en vee is gebuit. Te Erego het die Britte op 6 Oktober 1902 'n Pyrrhus-oorwinning (skynoorwinning) oor die Mullah behaal. Alhoewel die Mullah se verliese op 1150 beraam word, het die Britte self 187 ongevalle gely. Hierna is Britse garnisoene te Bohotle, Wadamago en Garrero gelaat waarna die Tweede Ekspedisie op 5 November 1902 tot ' $n$ einde gekom het toe luitenant-kolonel Swayne na Engeland teruggekeer het. ${ }^{60}$

\section{Die Somaliland Burgher Contingent en die Derde Ekspedisie teen die Mullah}

Op 4 November 1902 het brigadier-generaal W.H. Manning die leisels by luitenant-kolonel Swayne oorgeneem en begin om voorbereidings vir die naderende veldtog te tref deur onder andere ' $n$ groot aantal pakdiere aan te skaf en die garnisoen te Garrero van rantsoene te voorsien. Vanaf 22 Oktober tot en met 27 November het versterkings die land binnegekom en brigadier-generaal Manning het die garnisoene te Berbera, Hargeisa, Burao, Garrero en Bohotle gereorganiseer. ${ }^{61}$

Die Britte het besluit om die Mullah vanaf die ooskus van Somaliland aan te val. Reeds op 30 Oktober het die Italiaanse regering ingestem dat Brittanje die gebied kon verken met die doel om ' $n$ landingsplek vir die Britse troepe te identifiseer. Die Britse verkenningsgroep is deur die Italianers vergesel. Obbia is as die geskikste landingsplek uitgekies en Yusuf Ali, die plaaslike regeerder, het die Britte steun belowe in die vorm van 6000 kamele en 300 berede verkenners. Hy het egter nie sy belofte gestand gedoen nie. In Desember 1902 het Brittanje ook die steun van die Abessiniërs verkry. Die Abessiniërs sou verhoed dat die Derwisje weswaarts uitwyk voor die Britse opmars uit die ooste. Britse offisiere sou die Abessiniese magte organiseer en samewerking met die Britse magte koördineer. ${ }^{62}$

Die Britse ministerie van buitelandse sake het op 6 Desember 1902 die militêre en finansiële ver- pligtinge van die naderende veldtog aan die War Office oorgedra maar het steeds die politieke sake behartig. Die Indian Accounts Branch moes die rekeninge van die veldtog behartig. 'n Komitee bestaande uit verteenwoordigers van die ministerie van buitelandse sake en India en War Offices sou detail rakende die veldtog bespreek. ${ }^{63}$

Op 16 Desember 1902 het die Britse kabinet besluit om met die ekspedisie voort te gaan en die Italiaanse regering het finaal ingestem dat Britse magte te Obbia kon land. Die doel van die ekspedisie is aan brigadier-generaal Manning uiteengesit: hy moes die Mullah verslaan en hom van die oase van die Mudug verdryf. Hier sou nog ' $n$ Britse mag by hom aansluit wat dan gesamentlik die Derwisje weswaarts of noordwaarts moes verdryf indien moontlik. Berede troepe sou vir hierdie dryfjag aangewend word, maar dit moes nie langer as vier of vyf dae volgehou word nie. Brigadier-generaal Manning moes verhoed dat die Mullah suidwaarts na die Webi Shebell-vallei uitwyk aangesien laasgenoemde vanuit hierdie streek " $n$ bedreiging vir die Italiaanse Protektoraat en Britse Jubaland kon inhou. Manning moes self oor die roete van die opmars vanaf Obbia na die Mudug besluit. Paaie en waterputte moes in die Britse Protektoraat aangelê word, wat die militêre operasies sou vergemaklik en die ontwikkeling van die Protektoraat sou stimuleer. Laasgenoemde take is deur Manning uitgevoer. Manning sou in kennis gestel word van moontlike toekomstige Abessiniese samewerking. Op 17 Januarie 1903 het Keiser Menelik ingestem om sy oosgrens teen ' $\mathrm{n}$ Derwisje aanval te beskerm. $\mathrm{Na}$ afloop van die oorlog moes Manning die grootte van die garnisoen wat in die Somalilandse Protektoraat sou agterbly, bepaal. ${ }^{64}$

Brittanje wou egter nie die Mudug verower nie en die Italiaanse politieke-offisier wat brigadier-generaal Manning vergesel het, moes oor die toekoms van die streek besluit. ${ }^{65}$

Majoor P.A. Kenna en sy troepemag het Obbia op 26 Desember 1902 vanaf Berbera bereik met die doel om ' $n$ basis hier te vestig om sodoende die proses van ontskeping van die Somaliland Field Force te vergemaklik. Kenna het hier ' $n$ fort en 'n kamp vir die Somaliland Field Force gebou. Vee en voedsel is aangekoop en die omgewing is vir water, weivelde en roetes verken. Toe brigadiergeneraal Manning Obbia op 3 Januarie 1903 bereik, was die fort, die kamp en ' $n$ landingsplatform reeds

\footnotetext{
60 L. Bodin, The Mad Mullah of Somaliland, Part 1: Introduction, the First and Second Expeditions, Soldiers of the Queen 24, Feb 1981, pp 8-15. 
voltooi. ' $\mathrm{n}$ Pier en vlot is ook gebou. Laasgenoemde het die vervoer van diere na die strand vergemaklik. Al hierdie take is in ' $n$ ontstuimige see verrig. ${ }^{66}$

Die ontskeping van die troepe en voorrade het op 5 Januarie 1903 begin en op 16 Februarie 1903 tot ' $n$ einde gekom toe die laaste troepe en voorrade te Obbia afgelaai is. Die ontskeping is bemoeilik deur die ongunstige weer. Daar is nou ook tot die besef gekom dat Obbia nie die geskikste landingsplek was nie. Op 23 Januarie het die vaartuig Newark Castle, Obbia vanaf Kaapstad bereik. Dié skip het voorrade, muile en perde vervoer wat op 31 Januarie in die hawe ontskeep is. Op 25 Januarie 1903 het die stoomskip SS Gaul met die Somaliland Burgher Contingent en die 141 troepe van die King's Royal Rifle Corps asook 365 perde en voorrade aan boord, Obbia bereik. Dié twee skepe het die perde asook die 400 ponies en 400 muile met saals wat die Suid-Afrikaanse kontingent uit Suid-Afrika saamgeneem het, vervoer. Die Suid-Afrikaanse kontingent het voorts 500 rondtes ammunisie per geweer, 30000 rondtes per masjiengeweer en ses maande se voorrade saamgebring.$^{67}$

A. Hamilton, die Reuterskorrespondent in Somaliland, het die volgende oor die Suid-Afrikaanse kontingent te sê gehad: "Great expectations were formed upon the results of the work which the mounted contingents from South Africa would accomplish." ${ }^{68}$ Hamilton het beweer dat die kontingent van groot waarde sou wees aangesien hulle die krygsvaardighede wat hulle in die veld gedurende die AngloBoereoorlog aangeleer het, in Somaliland kon toepas. Verder het die hinterland van Obbia met die laeveld van die Transvaal ooreengestem en die bosse van Somaliland met dié van die hoëveld, alhoewel dit nie so vrugbaar was nie. ${ }^{69}$ Die lede van die kontingent het gevolglik nie heeltemal ontuis gevoel in die bosse van Somaliland nie.

Kaptein W.F. Bonham het hierdie siening van Hamilton onderskryf en soos volg oor die Somaliland Burgher Contingent geskryf na afloop van die veldtog: "The men have shown themselves to be particularly well suited for a campaign in this country as they support the climate better than English troops, and the experiences $+[$ sic] training of South African life enable them to adapt themselves more readily to the difficulties of campaigning in a roadless bush country." ${ }^{\prime 70}$
Vyftig lede van die King's Royal Rifle Corps en 25 lede van die Somaliland Burgher Contingent het met die moeilike proses van ontskeping gehelp. Op 25 Januarie is hierdie soldate aan wal gesit om na die perde wat reeds vanaf die Newark Castle aan wal gesit is, om te sien. Die ontskeping was ' $n$ uiters vermoeiende taak. Die voorrade moes ' $n$ afstand van ongeveer 1, 2 kilometer vanaf die strand tot by die voorrade-opslagplek vervoer word. Vir ses weke het soldate vanaf ligdag tot in die aand hul afgesloof om die voorrade vanaf die strand tot by die opgaarplek te dra aangesien geen lasdiere vir hierdie taak afgestaan kon word nie. Op 26 Januarie is die hele Suid-Afrikaanse kontingent ontskeep en op 30 Januarie is die laaste van die voorrade wat op die SS Gaul was, afgelaai. ${ }^{71}$

Terwyl die proses van ontskeping voortgeduur het, het die Somaliland Field Force 1000 kamele vanaf Berbera en 500 kamele in die Obbia-streek verkry. Dié diere is as pakdiere, rydiere en as ' $n$ bron van voedsel aangewend en was gevolglik ' $n$ uiterste noodsaaklikheid gedurende die veldtog. ${ }^{72}$

Die deel van die Somaliland Field Force wat te Obbia geland het, was 2296 man sterk en het uit die volgende komponente bestaan: die Britse en Burger kontingente van Suid-Afrika wat onderskeidelik 141 en ongeveer 100 man sterk was; een kompanie Punjab Mounted Infantry, 150 man sterk en 550 man van die King's African Rifles vanaf Berbera; 200 man van die Bikanir Camel Corps, een Seksie van die Native Mountain Battery met twee kanonne, een kompanie Sappers en Miners, 2nd Sikh Infantry, een Native Field Hospital en een seksie British Field Hospital vanaf Indië. Dié kosmopolitaanse mag het dus uit Boerekrygers, Britte, Indiërs en swart Afrikane bestaan. Die troepemag te Berbera was 1745 man sterk. ${ }^{73}$

Teen die begin van Februarie het brigadier-generaal Manning voorposte te Gabarwein, Lodobal, El Dibber en Dibit gevestig, voorrade en water in houers is hier gestoor en die waterputte is oopgemaak. Daar is besluit dat die opmars na die Mudug deur bogenoemde poste sou plaasvind aangesien water hier aanwesig was en daar geen sandduine op die roete was, wat die aanmars kon belemmer nie. Patrollies van die Bikanir Camel Corps het die gebied vanaf Dibit in die rigting van Galkayu bespied en vasgestel dat die geskikste roete om Galkayu te bereik, deur Rhakn en Wargallo strek. Daar is

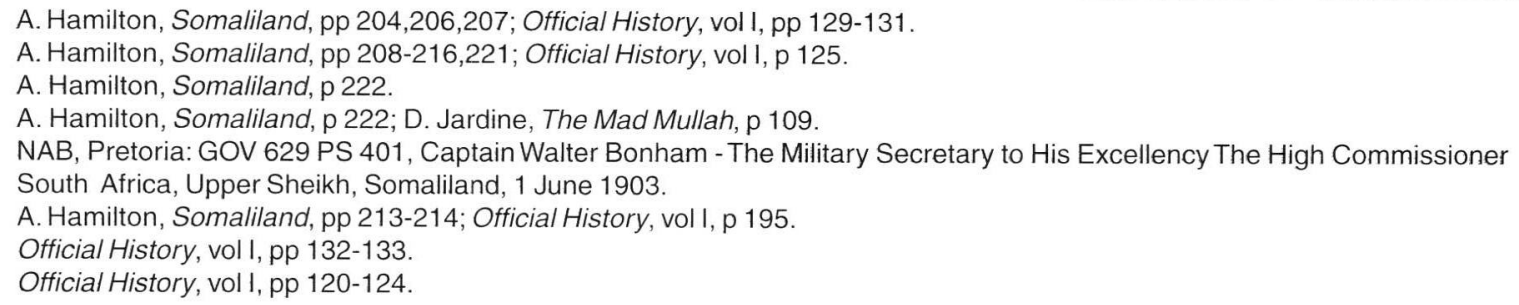


gevolglik op hierdie roete besluit. Die Britte het nou vermoed dat die Mullah hom in die Galadi-distrik bevind het. ${ }^{74}$

Die waterskaarste in die gebied en die tekort aan lasdiere om die water te vervoer het die Britse opmars belemmer. Dit het die grootte van die leër beperk en ook die moontlikheid om die Mullah te verras uitgeskakel aangesien die opmars langs ' vasgestelde roete moes geskied. ${ }^{75}$

Luitenant-kolonel J.C. Swann, die bevelvoerder van die Berbera-Bohotle kontingent, is op 17 Februarie 1903 deur brigadier-generaal Manning beveel om ' $n$ waterbron te Damot te vestig. ' $n$ Mag moes Damot teen 16 Maart vanaf Bohotle beset. Nadat kommunikasieverbinding tussen Damot en Galkayu verkry is, moes Swann na 30 Maart 'n mag in die rigting van Galkayu uitstuur om sodoende kontak met die Obbia mag te maak. ${ }^{76}$

Op 22 Februarie 1903 het brigadier-generaal Manning met ' $n$ mag vanaf Obbia na Gabarwein opgeruk. Drie offisiere en 50 lede van die Somaliland Burgher Contingent en twee offisiere en 50 lede van die British Mounted Infantry (King's Royal Rifle Corps) was deel van die kontingent. Lede van die Somaliland Burgher Contingent en die British Mounted Infantry is slegs toegelaat om elk 6,75 kilogram (15 pond) bagasie saam te neem op die tog. Rantsoene vir veertien dae het onder andere brood, vleis en graan ingesluit en reserwe voorrade vir elf dae is ook saamgeneem. Majoor P.A. Kenna het die berede troepe aangevoer wat ook 100 soldate van die Punjab Mounted Infantry en 75 lede van die Bikanir Camel Corps ingesluit het. Die res van die kontingent het uit die infanterie-eenhede, die King's African Rifles en 2nd Sikh Infantry bestaan. Nog troepe sou by die kolonne aansluit op die tog na Galkayu. Daar was altesame 1138 troepe onder Manning se bevel. ${ }^{77}$

Luitenant-kolonel C.G.M. Fasken was in bevel van die magte wat by Obbia agtergebly het. Dit het die ander helfte van die Somaliland Burgher Contingent en die grootste deel van die King's Royal Rifle Corps ingesluit. Fasken was weens die tekort aan vervoermiddele en water op die roete na Galkayu, genoodsaak om hier agter te bly en sy kolonne in twee te verdeel. Fasken se kolonne van 807 man was voorsien van een maand se rantsoene. ${ }^{78}$
Brigadier-generaal Manning se aanmars vanaf Obbia na Galkayu was 'n uitmergelende proses wat in uiterste hitte plaasgevind het. Veral die berede troepe onder majoor Kenna het swaar gekry, alhoewel slegs een perd op die roete gevrek het. Die soldate in die kolonne het 04:30 opgestaan en om 07:00 die kamp verlaat. Aan die einde van 'n dag se trek is kamp opgeslaan. Kampe was vierkantig, ongeveer 130 meter lank en 150 meter breed. Die skansmuur (zariba) van die kamp is van bos of klip gekonstrueer en was ongeveer 1, 2 meter hoog en is so wyd moontlik gemaak. Dit is deur doringdraad omring. Maxim-masjiengewere is op elke hoek van die skansmuur geplaas en 'n reserwemag van infanterie is altyd op ' $n$ gereedheidsgrondslag geplaas. Wagte is ook ' $n$ entjie vanaf die kamp uitgestuur om vroegtydig vyandelike bewegings te identifiseer. Wapens is nooit gestapel nie en moes altyd byderhand gehou word. ' $n$ Hoë standaard van higiëne is in en rondom die kamp gehandhaaf. ${ }^{79}$

Brigadier-generaal Manning het sy troepe gedurende die veldtog hoofsaaklik in ' $n$ vierkant laat marsjeer in ruie en ook oop terreine. Die infanterie het die voor- en agterhoede gevorm terwyl die berede troepe die flanke beskerm het. Die kamele het in die middel geloop. Agt tot tien berede Somaliërs wat voor die kolonne uitgery het, het die rigting en marsorde met vlae aangedui. Somaliese berede infanterie het die gebied rondom die kolonne verken en verkenners is daagliks 32 tot 48 kilometer ver vooruitgestuur om die gebied te verken. Wanneer kamp opgeslaan is, moes elke flank sy eie skansmuur oprig. Manning het sy kolonne nooit in die donker laat marsjeer nie. Indien die kolonne gedurende ' $n$ marstog aangeval is, het die infanterie uitgesprei om ook ' $n$ deel van die syflanke te verdedig. Die marsformasie het soms uitgerek omrede die kamele nie gewoond was om in sulke formasies te loop nie. ${ }^{80}$

Manning gee die volgende beskrywing van die aanmars: "Crossing the very dense bush of the Haud in this formation as much as 25 miles per diem was accomplished, and it was often the case that until the midday or evening halt the troops forming the front face were hardly ever visible to me except those marching behind the centre flagman." ${ }^{1}$

Op die tog van 40 kilometer vanaf Obbia na Lodobal het Manning se kolonne aanvanklik bossies gras en struikgewas en later lae sandduine teëgekom. ${ }^{82}$

Official History, vol I, pp 134-135; A. Hamilton, Somaliland, p 235.

Official History, vol I, pp 135-136.

Official History, vol I, pp 136-138; A. Hamilton, Somaliland, pp 237-240.

Official History, vol I, pp 140-141,185,186; A. Hamilton, Somaliland, p 241

Official History, vol I, pp 141,145. A. Hamilton verskil egter met die Official History oor die wyse waarop Fasken sy kolonne verdeel

het. Eersgenoemde beweer dat Fasken sy magte in vier kolonnes van 200 man elk verdeel het, pp 246-247.

A. Hamilton, Somaliland, pp 242,358-359; Official History, vol I, pp 141,144, 324.

Official History, vol I, pp 325-326; A. Hamilton, Somaliland, p 242.

Official History, vol I, p 325.

Official History, vol I, p 141. 
Baie wildlewe is ook teëgekom. Die berede troepe onder aanvoering van majoor Kenna, waaronder die Suid-Afrikaanse kontingent van ongeveer 100 man, het afsonderlik van die infanterie marsjeer en het waarskynlik die flanke van die kolonne gevorm. Op 24 Februarie is El Dibber bereik, 'n afstand van amper 29 kilometer van Lodobal af. Die voorhoede onder majoor R.G. Brooke, het Wargallo ingeneem en het die waterbronne hier verbeter. Twee dae later het die hele kolonne te Dibit vergader en deur Inideenli na Rhakn opgeruk. Die water te Rhakn was egter nie voldoende nie en 170 kamele en die berede troepe waaronder die 50 lede van die Somaliland Burgher Contingent en die 50 lede van die British Mounted Infantry moes na Inideenli terugkeer - 20 kilometer vanaf Rhakn - aangesien hier meer water was. Die tog vanaf Dibit tot in Inideenli is vergemaklik deur die oop landskap waaroor die troepe beweeg het. ${ }^{83}$

Op 2 Maart is 80 soldate van die Punjab Mounted Infantry en die Bikanir Camel Corps onder leiding van kaptein A. Williamson, na Galkayu uitgestuur om te verhoed dat die waterbronne te Wargallo uitgeput raak. Gedurende die volgende dag het Manning se kolonne Wargallo bereik waar die berede troepe hulle by die kolonne aangesluit het na' $n$ marstog deur Rhakn. Vervolgens het die berede troepe van die kolonne Wargallo verlaat en op 4 Maart Galkayu bereik en hier kaptein A. Williamson aangetref, wat ' $n$ kamp vir Galkayu se verdediging opgerig het. Die hele kolonne het die volgende dag Galkayu bereik waar die watervoorraad voldoende was. Die marstog tussen Obbia en Galkayu, 'n afstand van 256 kilometer, het twaalf dae geneem om af te lê. Die Derwisje het intussen weswaarts uitgewyk voor die naderende bedreiging. ${ }^{84}$

Luitenant-kolonel C.G.M. Fasken se hoofkolonne het Obbia op 6 Maart verlaat. Die 52 lede van die Somaliland Burgher Contingent en 87 lede van die British Mounted Infantry (King's Royal Rifle Corps), wat deel van die kolonne was, is dus nou ook direk by die operasies teen die Mullah betrek. Soos reeds bespreek is, het Fasken se kolonne in kleiner kolonnes verdeel weens die tekort aan water en gebrek aan vervoer. Daar was nie voldoende voer vir die kamele wat as pakdiere gebruik en alreeds deur die seetog tussen Berbera en Obbia, verswak is nie. Die 52 lede van die Somaliland Burgher Contingent en die helfte van die 87 man sterk British Mounted Infantry, was deel van die eerste groep van Fasken se kolonnes wat Obbia verlaat het aangesien die volle waterreserwes op die roete vir die perde van dié eenhede benodig is. Die tekort aan water, nieteenstaande die grawe van waterputte en die vermindering van die waterrantsoene, was 'n ernstige probleem. Hierdie toedrag van sake is vererger deur die intense hitte wat ervaar is. Gevolglik het luitenant-kolonel Fasken besluit dat sy kolonnes gedurende die nag sou marsjeer. Hierdie stap het groot verligting gebied aan die troepe wat, in teenstelling met brigadier-generaal Manning se kolonne, in die koeler nagure kon marsjeer. ${ }^{85}$

Te Galkayu het brigadier-generaal Manning op luitenant-kolonel Fasken se kolonnes gewag. Manning wou 'n aanval teen die Derwisje loods sodra Fasken se kolonnes hier arriveer het. Laasgenoemde kolonnes sou Manning se troepemagte en voorrade aanvul. Verder is Manning genoodsaak om te Galkayu te vertoef aangesien hy 850 kamele na Dibit teruggestuur het om voorrade saam met die hoofkolonnes onder Fasken na Galkayu te bring. Patrollies is uitgestuur en daar is vasgestel dat die Mullah se magte wes van Galkayu, te Galadi saamgetrek was en dat die Mullah self hom te Dikwein bevind het. ${ }^{86}$

Intussen was die Berbera-Bohotle-mag onder luitenant-kolonel Swann nie ledig nie. Swann het majoor J.E. Gough op 3 Maart na Damot gestuur om dié plek in te neem. Gough het Damot op 4 Maart 1903 ingeneem nadat ' $n$ klein mag Derwisje hier verdryf is. Nadat ' $n$ kamp te Damot opgerig is, het Gough sy infanterie hier as ' $n$ garnisoen agtergelaat en na Bohotle teruggekeer. ' $n$ Tweede mag onder luitenant-kolonel A.W.V. Plunkett is op 10 Maart vanaf Bohotle uitgestuur met die doel om Lasakante waterputte, 48 kilometer suid van Bohotle, in te neem. Dié plek is ingeneem en omrede die waterputte hier nie voldoende water bevat het nie, is dit toegegooi en Plunkett het na Bohotle teruggekeer. Teen 13 Maart het brigadier-generaal Manning daarin geslaag om een van die opdragte wat hy van die Britse owerhede ontvang het, ten uitvoer te bring deur direkte kommunikasie tussen Damot en Galkayu te bewerkstellig. ${ }^{87}$

Luitenant-kolonel Swann het Damot op 14 Maart bereik, dit as hoofkwartier van die Berbera-Bohotlekolonne ingerig en ' $n$ telegraafstasie opgerig. Die eerste kolonne van luitenant-kolonel Fasken, waaronder die 52 lede van die Somaliland Burgher Contingent en die helfte van die 87 lede van die British Mounted Infantry, het Galkayu op 17 Maart bereik. ' $n$ Week later was Fasken se hele kolonne te Galkayu saamgetrek. Verdere versterkings onder leiding van luitenant-kolonel Plunkett, wat water en rantsoene saamgebring het, het Galkayu vanaf

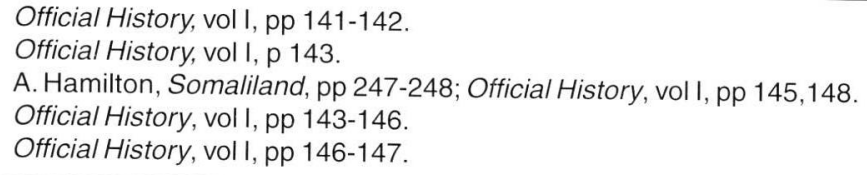


Damot op 25 Maart bereik. ${ }^{88}$ Die hele Suid-Afrikaanse kontingent was nou vir die eerste keer almal op een plek saamgetrek.

Intussen het die Mullah se magte steeds nie tot die aanval oorgegaan nie en vanaf Galadi verder weswaarts naWardair en Walwal teruggeval. Brigadier-generaal Manning is vroeër deur die Britse regering opdrag gegee om nie ' $n$ marstog van langer as vier of vyf dae vanaf Galkayu te onderneem nie. Manning was egter nou verplig om na Wardair en Walwal op te ruk wat 241 kilometer vanaf Galkayu geleë was en wat dus verder as vier of vyf dae se marstog was. Gevolglik het die Britse owerhede Manning carte blanche gegee wat betref operasies in die gebied maar hy moes egter steeds verhoed dat die Mullah na die suide uitwyk. ${ }^{89}$

'n Kolonne bestaande uit 1081 man onder brigadier-generaal Manning het Galkayu op 26 Maart 1903 verlaat nadat ' $n$ garnisoen hier agtergelaat is en na Bera opgeruk met die doel om die magte van die Mullah aan te keer. Die hele Suid-Afrikaanse kontingent was nou deel van die mag wat Manning vergesel het. Majoor A.G. Sharp wat die Bohotle mag aangevoer het, moes verhoed dat die Mullah die Nogal Plein betree en majoor R. Brooke moes vanaf Badwein, noord van Bera, keer dat die Mullah nie oor die Haud na die Nogal uitwyk nie. Laasgenoemde twee troepemagte het met die vyand slaags geraak en vee gebuit. ${ }^{90}$

Manning se kolonne het die afstand van 24 kilometer tussen Galkayu en Bera sonder teenstand afgelê en hulle bestemming op 26 Maart bereik. Majoor Kenna, met tussen 240 en 300 man van die Somaliland Burgher Contingent en die British Mounted Infantry, het die pad na Dudub verken - 'n afstand van 71 kilometer van Bera af - en op 28 Maart die plek beset en 'n paar Derwisje gevange geneem. Op 30 Maart het die res van Manning se kolonne Dudub bereik en "n garnisoen hier gelaat. Manning het intussen 338 van sy infanterie na Galkayu teruggestuur. Op dieselfde dag het majoor Kenna en sy Britse en Boere berede infanterie Galadi bereik en hier met vyandelike perderuiters en spiesdraers slaags geraak. Vyf Derwisje is gedood en vyftien is gevange geneem. ' $n$ Paar Derwisjvroue en kinders is ook gevange geneem en 130 kamele en 2000 bokke is gebuit. Die kolonne onder brigadier-generaal Manning het Galadi op 31 Maart bereik en die watervoorraad hier was voldoende vir 'n klein mag. ${ }^{91}$

Baie kamele en perde het gevrek op die tog na Galadi weens die tekort aan water en rantsoene. Die Reuters-oorlogskorrespondent, A. Hamilton het so verslag gedoen oor die tog na Galadi: "Few armies would have sustained for a similar length of time the severe privations that the force endured through the shortness of water and the inadequacy of supplies." ${ }^{92}$ Kaptein Bonham het in sy verslag oor die veldtog verklaar dat ' $\mathrm{n}$ lid van die Somaliland Burgher Contingent, genaamd Jan Swarts, naby Galadi verlore geraak het. Die lid is nie opgespoor nie. Bonham spesifiseer nie die omstandighede waaronder hierdie lid verlore geraak het nie. ${ }^{93}$

Brigadier-generaal Manning was verplig om by Galadi te vertoef om die nodige voorrade te bekom. Die tog vanaf Galkayu deur Galadi na Walwal en Wardair het oor ' $n$ moeilik begaanbare terrein gestrek. Manning het nou 'n plan beraam om sy kolonne vanaf Galadi naWalwal en Wardair te mobiliseer. ' $n$ Waterpunt is 32 kilometer vanaf Galadi opgerig in die rigting van Walwal en Wardair met ' $n$ tweede, 24 kilometer van die eerste af. Vanaf laasgenoemde waterpos moes die kolonne dan self vyf dae se watervoorraad in watertenks saamkarwei. Daar is gereken dat daar voldoende water te Wardair sou wees. Intussen is twee patrollies vroeg in April onderskeidelik in ' $n$ westelike en suidelike rigting uitgestuur met die doel om kamele te buit om sodoende die tekort aan pakdiere uit te wis. Die verkenningstogte het 1630 kamele opgelewer en beide patrollies het met die Derwisje slaags geraak. ${ }^{94}$

Luitenant-kolonel A.S. Cobbe is op 10 April 1903 met 415 manskappe van 1, 2 en 6 Bataljonne King's African Rifles en die Camel Battery in die rigting van Wardair uitgestuur. Cobbe moes die roete na Wardair verken en vasstel of die Mullah hom nog daar bevind het. Cobbe het ook opdrag gehad om kamele te buit aangesien daar steeds ' $n$ tekort aan pakdiere was en hy moes Wardair beset indien geringe teenstand daar teëgekom sou word. Verder moes die watervoorraad te Wardair en Gumburu verbeter word ${ }^{95}$ Cobbe sou egter nie hierdie doelwitte bereik nie.

Drie dae later het kaptein G.C. Shakerley van die King's Royal Rifle Corps met 'n mag van twee offi-
8

Official History, vol I, pp 145,147-148; A. Hamilton, Somaliland, pp 247,253. Plunkett se versterkings het 300 man van 2 Bataljon King's African Rifles, 50 man van die Somali Mounted Infantry en twee kanonne van die Camel Battery ingesluit.

89 Official History, vol I, pp 148-149,151-152.

90 A.Hamilton, Somaliland, pp 254,255; Official History, vol I, pp 149-150. Die ander troepe onder Manning se bevel was 1, 2 en 5 Bataljonne King's African Rifles, die Bombay Sappers and Miners en die 2nd Sikh Infantry.

Official History, vol I, pp 149-151; A. Hamilton, Somaliland, pp 226-257

A. Hamilton, Somaliland, pp 257-258.

93 NAB, Pretoria: GOV 629 PS 401, Captain Walter Bonham - The Military Secretary to His Excellency The High Commissioner South Africa, Upper Sheikh, Somaliland, 1 June 1903.

94 Official History, vol I, pp 148,152-153; A. Hamilton, Somaliland, pp 260-261

95 A. Hamilton, Somaliland, pp 262-264; Official History, vol I, pp 153-154. 
siere en 21 onderoffisiere en manskappe van die British Mounted Infantry en een offisier en 22 onderoffisiere en manskappe van die Somaliland Burgher Contingent by luitenant-kolonel Cobbe se mag aangesluit, wat in die rigting van Gumburu - 48 kilometer van Galadi af - gemarsjeer het. Gedurende die middag van dieselfde dag is Shakerley se berede mag tesame met die Somali Mounted Infantry dertien kilometer vooruit gestuur in die rigting van Gumburu. Dié berede patrollie het egter in die digte bos verdwaal en geen kontak kon met hulle gemaak word nie. Gevolglik het Cobbe besluit om op 'n afstand van 85 kilometer van Galadi af, in die rigting van Gumburu, kamp op te slaan. ${ }^{96}$

Aangesien die bos al hoe meer ondeurdringbaar geword het en die pad deur die bos nie gevind kon word nie, het luitenant-kolonel Cobbe op 14 April besluit om terug te draai in die rigting van Galadi. Sy mag is deur berede Derwisje aangeval. Kaptein Shakerley en die berede troepe het die lawaai van die botsing gehoor en daarin geslaag om Cobbe se mag op te spoor en gesamentlik het hulle die Derwisje verdryf. Cobbe se mag het hierna noord van Gumburu Hill, ' $n$ afstand van elf kilometer van Gumburu en 68 kilometer van Galadi af, kamp opgeslaan. Die volgende dag het ' $n$ reënbui uitgesak wat Cobbe se yl waterrantsoene aangevul het. Op 16 April het ' $n$ konvooi vanaf Galadi Cobbe bereik met rantsoene en ekstra watervoorraad. ${ }^{97}$

Gedurende dieselfde dag het luitenant-kolonel Cobbe patrollies na die wes-suidweste, weste en suidsuidooste uitgestuur. Kaptein Shakerley en 'n berede patrollie is na die noorde uitgestuur. Skote is gehoor in die rigting van kaptein Luard se patrollie wat in ' $n$ wes-suidwestelike rigting uitgestuur is. Die patrollie van kaptein Morris wat in ' $n$ westelike rigting uitgestuur is, het ook met die vyand kontak gemaak maar het nie tot die aanval oorgegaan nie. Die berede troepe van Cobbe se mag, wat lede van die Somaliland Burgher Contingent en die British Mounted Infantry ingesluit het, is gestuur om kaptein Morris te hulp te snel. Toe die berede troepe Morris bereik, het die vyand reeds spoorloos verdwyn. Kaptein Luard het die vyand waarmee hy vroeër kontak gemaak het, agtervolg. Nadat Morris na die kamp teruggekeer het, is ' $n$ berede mag onder kaptein Shakerley wat uit: een offisier en vier man van die British Mounted Infantry, een offisier en twaalf man van die Somaliland Burgher Contingent en een offisier en twaalf man van die Somali Mounted In- fantry bestaan het, in ' $\mathrm{n}$ westelike rigting uitgestuur. ${ }^{98}$

Luitenant-kolonel Cobbe was oortuig daarvan dat die Derwisje in die digte bos 16 tot 19 kilometer vanaf sy kamp saamgedrom het. Kaptein Shakerley en sy berede mag, wat weswaarts uitgestuur is, het op ' $n$ afstand van ongeveer 2,4 kilometer vanaf die kamp kontak gemaak met drie Derwisje verkenners en hulle agtervolg. Op ' $n$ afstand van drie kilometer vanaf die kamp het Shakerley en sy Boere, Britse en Somaliese soldate met ' $n$ groot berede Derwisj-mag van ' $n$ paar honderd slaags geraak. Die Derwisje het gepoog om hierdie mag te omsingel waarop Shakerley ongeveer 36 meter teruggeval en sy troepe in ' $n$ sirkel laat stelling inneem het. Shakerley het Cobbe om hulp gevra en laasgenoemde het dadelik versterkings uitgestuur. Die Derwisje het hul aanval vir ' $n$ driekwart uur dapper volgehou en selfs binne elf meter van Shakerley se stelling gevorder waarna hulle teruggeval het. $\mathrm{Na}$ afloop van die botsing het kaptein Luard van die King's African Rifles met sy kompanie infanteriste by Shakerley opgedaag nadat hulle die skote gehoor het. Hierna het die versterkings wat deur Cobbe uitgestuur is, opgedaag. Dit is moontlik dat die Derwisje bewus was van kaptein Luard se naderende kompanie en gevolglik besluit het om terug te val. Die Britte het tydens die skermutseling vier ongevalle gely. Luitenant C.E. Chichester van die Somali Mounted Infantry is gedood, R.J.G. Hill van die Somaliland Burgher Contingent en nog twee Somaliërs is gewond. Shakerley het gereken dat die Derwisje ongeveer 200 ongevalle gely het. ${ }^{99}$

Kaptein Shakerley, skutter Joshef Miller van die King's Royal Rifle Corps, kaptein W.L. Foster wat die lede van die Somaliland Burgher Contingent tydens bogenoemde skermutseling aangevoer het en skutter Mandelumbe van 2 Bataljon King's African Rifles, is na afloop van die botsing geloof vir hulle dapper optrede. ${ }^{100}$ Luitenant-kolonel Cobbe het soos volg oor die botsing geskryf: "...the very steady behaviour of the British and Burgher Mounted Infantry, which alone enabled them to keep off the enemy until the appearance of the infantry made the enemy retire."101

Volgens kaptein Bonham was die skermutseling naby Gumburu die enigste geval waar lede van die Somaliland Burgher Contingent en die British Mounted Infantry met die Mullah se magte slaags

\footnotetext{
Official History, vol I, pp 155-156,161.

Official History, vol I, pp 156-157,162; A. Hamilton, Somaliland, p 265

Official History, vol I, pp 157-158,162,168.

Official History, vol I, pp 162-163,165,168-169; A. Hamilton, Somaliland, p 265; NAB, Pretoria: GOV 629 PS 401, Copy of Telegram Bonham - Lord Milner Johannesburg, Aden, 24 April; $\underline{\text { lbid, }}$, Commander Natal District - The Secretary to the High Commissioner Pretoria, Head Office Natal District, Pietermaritzburg, 21 July 1903.

100 Official History, vol I, pp 165,168-169; A. Hamilton, Somaliland, p 270

101 Official History, vol I, p 165.
} 
geraak het. ${ }^{102}$ Volgens die skrywer was daar egter nog twee sulke skermutselings wat reeds hierbo bespreek is. Die kontingente van Suid-Afrika sou nie weer met die vyand slaags raak nie. Die enigste geval waar van die berede magte van dié twee kontingente verder aan ' $n$ belangrike operasie sou deelneem was op 18 April, 'n dag na die fiasko te Gumburu.

\section{Die terugslae te Gumburu en Daratoleh en die beëindiging van die Derde Ekspedisie}

Op hierdie tydstip was 238 lede van die Somaliland Burgher Contingent en die British Mounted Infantry nog deel van brigadier-generaal Manning se kolonne te Galadi. Na die skermutseling met die Derwisje het luitenant-kolonel Cobbe besluit om nie van posisie te versit nie. Laasgenoemde besluit sou verreikende gevolge hê. ${ }^{103}$

'n Dag na kaptein Shakerley se skermutseling met die Derwisje is ' $n$ mag bestaande uit twee kompanies van 2 Bataljon King's African Rifles en sowat 50 manskappe van 2nd Sikh Infantry met twee maxim-masjiengewere onder aanvoering van luitenant-kolonel A.W.V. Plunkett, tien kilometer wes van luitenant-kolonel Cobbe se kamp deur ' $n$ Derwisje mag te Gumburu verslaan. Die mag was deel van luitenant-kolonel Cobbe se kolonne. Nege offisiere is gedood en 187 man het in die stryd omgekom. Daar is gemeen dat die Mullah self sy magte tydens dié slag aangevoer het. Cobbe se kamp is egter nie deur die Derwisje aangeval nie. Op 18 April het majoor Kenna met 100 berede infanterie van die Somaliland Burgher Contingent en British Mounted Infantry by Cobbe se kamp opgedaag met die opdrag van brigadier-generaal Manning dat hy na Galadi moes terugval. Gedurende die volgende dag het Cobbe gehoor gegee aan hierdie bevel. Op 19 April het Cobbe en Manning se kolonnes mekaar 16 kilometer vanaf Gumburu ontmoet en saam Galadi op 20 April bereik sonder dat hulle deur die Derwisje lastig geval is. ${ }^{104}$

Die bevelvoerder van die Obbia magte het besluit om sy aanval op Wardair enWalwal uit te stel weens die Gumburu-fiasko, ' $n$ tekort aan water en aan kamele om rantsoene te vervoer, asook onvoldoende troepe om die gevaarlike gevegsterrein wat uit ruie bosse bestaan, te trotseer. Luitenant-kolonel Fas- ken het Galadi op 17 April met 'n mag van 530 man bereik. Brigadier-generaal Manning het nou 1085 manskappe by hom gehad, insluitende al die lede van die Somaliland Burgher Contingent en die kompanie King's Royal Rifle Corps (British Mounted Infantry). ${ }^{105}$

Op 22 April 1903 is nog 'n Britse mag van 403 man sterk, wat deel van die Berbera-Bohotle kolonne was, te Daratoleh noord van Gumburu deur 'n Derwisj-mag, van ongeveer 800 man sterk, verslaan. Hierdie Britse mag was veronderstel om met luitenant-kolonel Cobbe se mag kontak te maak, informasie oor die Mullah se bewegings in te win, te verhoed dat hy na die noorde of noordooste uitwyk en om vee te buit. Ses dae later het hierdie mag onverrigter sake na Bohotle teruggeval. ${ }^{106}$

$\mathrm{Na}$ Gumburu en Daratoleh is garnisoene te Galadi en Dudub gestasioneer. Die Somaliland Burgher Contingent, British Mounted Infantry en al die berede infanterie is te Bera gestasioneer aangesien dit die enigste plek was waar daar voldoende voer vir die perde was. Die res van die Obbia-mag is te Galkayu en tussen Badwein in die noorde en Obbia in die suide gestasioneer. Brigadier-generaal Manning het aan die einde van April besluit om gedurende Mei van sy troepe, insluitende die Somaliland Burgher Contingent en ' $\mathrm{n}$ deel van die Mountain Battery, na Bohotle te onttrek. Die Britse regering het op 5 Mei besluit dat Manning weens die gebrek aan pakdiere en voorrade al sy magte te Bohotle moes saamtrek en nie in die Mudug moes aanbly nie. Gedurende Mei is die poste te Galkayu, Bera, Dudub en Galadi steeds bewaak en al die surplus rantsoene en die manskappe wat nie garnisoendiens verrig het nie, is na Bohotle ontruim. Die Mullah wat hom te Walwal bevind het, het die Britse magte nie lastig geval nie. ${ }^{107}$

Die Somaliland Burgher Contingent is dus vanaf Galadi na Bera ontruim, vandaar is hulle na Bohotle en laastens na Berbera onttrek waar die kontingent Somaliland op 12 Junie 1903 verlaat het. ${ }^{108}$

Al die oorblywende magte in die Mudug-streek het op 17 Junie 1903 te Badwein noordoos van Bera vergader en na Damot marsjeer. Vyftig lede van die British Mounted Infantry wat toe nog in die streek was, het die mag vergesel. Op 26 Junie is die oorblywende magte te Bohotle gekonsentreer en op 3 Julie het ook die Damot-garnisoen, Bohotle bereik

\footnotetext{
102 NAB, Pretoria: GOV 629 PS 401, Captain Walter Bonham - The Military Secretary to His Excellency The High Commissioner South Africa, Upper Sheikh, Somaliland, 1 June 1903.

Official History, vol I, p 157.

Official History, vol I, pp 163-164,169-170; A. Hamilton, Somaliland, pp 270, 272.

Official History, vol I, pp 171-172.

Official History, vol I, pp 172-173,177-179.

Official History, vol I, pp 184-185,187,189

Official History, vol I, p 200.
} 
Al die Britse magte was dus nou weer in die Britse Protektoraat saamgetrek. Intussen het die Mullah met sy volgelinge tussen Damot en Bohotle in die rigting van die Nogal Vallei deurgebreek sonder om met die Britse magte slaags te raak. ${ }^{109}$

Alhoewel die Abessiniese magte die Derwisje twee keer verslaan het, moes hulle hul veldtog weens ' $n$ tekort aan rantsoene en 'n gebrek aan kommunikasie met die Britse kolonnes, op 7 Junie aflas. Die Britse owerhede wou gehad het dat die Abessiniërs Wardair vanuit die weste aanval.' $n$ Algehele gebrek aan kommunikasie het hierdie plan laat misluk en verhoed dat dié bondgenote ' $n$ gelyktydige aanval teen die Mullah loods. ${ }^{110}$

Van die laaste maatreëls wat brigadier-generaal W.H. Manning getref het, was om die garnisoene op die Berbera-Bohotle lyn te versterk. Op 3 Julie 1903 het die Derde Ekspedisie teen die Mullah tot 'n onglorieryke einde gekom toe generaal-majoor C.C. Egerton die bevel van die Somaliland Field Force oorgeneem het. ${ }^{111}$

$\mathrm{Na}$ afloop van die veldtog het kaptein Bonham die kontingent geloof vir hulle optrede tydens die veldtog. Kaptein Bonham het verklaar dat die veldtog baie van die lede geverg het aangesien hulle in die uiterste hitte moes marsjeer en met die minimum rantsoene en water tevrede moes wees. ${ }^{112}$

\section{Demobilisasie en Vergoeding}

Die Somaliland Burgher Contingent, nou onder bevel van kaptein A.A. McHardy, het op 10 Junie 1903 te Berbera aan skeep gegaan en twee dae later terug na Suid-Afrika vertrek. Daar is besluit om by Durban aan wal te gaan en nie by Kaapstad nie aangesien dit vir die lede van die kontingent, wat hoofsaaklik uit Transvalers en Vrystaters bestaan het, makliker sou wees om vanaf Durban na hul wonings te reis. Reëlings vir die ontskeping te
Durban is getref deur die Britse militêre owerhede. Die kontingent het Durban op 13 Julie 1903 bereik en is op dieselfde dag ontbind. ${ }^{113}$

Voor die kontingent se aankoms in Durban, het die Britse Minister van Kolonies, Joseph Chamberlain vir Goewerneur Alfred Milner op 18 Junie opdrag gegee: "...to afford them such a reception as will show an appreciation of the excellent service they have rendered." ${ }^{114}$ Chamberlain het voorgestel dat Milner die Somaliland Burgher Contingent moes toespreek met hul terugkeer. Op dieselfde dag het die koloniale kantoor die War Office meegedeel dat dit Chamberlain se wens was dat brigadier-generaal W.H. Manning ' $n$ skrywe aan Goewerneur Alfred Milner moes stuur waarin eersgenoemde sy waardering vir die diens wat die kontingent in Somaliland verrig het, moes uitspreek. Dit sou volgens die koloniale kantoor: "...a useful political effect in South Africa" hê. ${ }^{115}$

Beide wense van Chamberlain is uitgevoer. Die taak om die kontingent met hul terugkeer persoonlik toe te spreek om sodoende Brittanje se dank en waardering aan die kontingent vir die diens wat hulle in Somaliland gelewer het oor te dra, het eindelik op die skouers van brigadier-generaal Robert George Broadwood geval wat die kontingent tydens hul aankoms in Durban toegespreek het. Broadwood het hierdie opdrag van generaal Neville Lyttelton, die Britse Opperbevelvoerder (Commander-inChief) in Suid-Afrika, ontvang. Broadwood het gedurende die Anglo-Boereoorlog die South African Light Horse aangevoer. ${ }^{116}$

Brigadier-generaalW.H. Manning het in sy skrywes en in ' $n$ verslag oor die Derde Ekspedisie teen die Mullah lof aan die Somaliland Burgher Contingent toegeswaai. Hy het ook aan Chamberlain se wens uitvoering gegee deur Goewerneur Milner in 'n telegraaf mee te deel dat hy die dienste van die kontingent hoog op prys gestel het. Manning het voorts

109 Official History, vol I, pp 190,193-194.

10 Official History, vol I, pp 181-184.

11 Official History, vol I, p 195

12 NAB, Pretoria: GOV 629 PS 401, Captain Walter Bonham - The Military Secretary to His Excellency The High Commissioner South Africa, Upper Sheikh, Somaliland, 1 June 1903.

113 NAB, Pretoria: LTG, Houer 114, Lêer 102/3 vol I, (Capt Scott Hardin War Gratuity-Somaliland), Brief, (Signed) H.S. Scott Harden Capt. Late Lieut Burgher Contingent - Lieutenant Governor of the Transvaal Colony, Bloemfontein, 10 November 1903; NAB, Pretoria: LTG, Houer 165, Lêer F1, (Code Telegrams Secretary of State 1 June to 4 July 1903), No 565 Boers returning after serving in Somaliland, Copy of Telegram no 2 Governor Johannesburg - Secretary of State London, 30 June; NAB, Pretoria: LTG, Houer 114, Saamgebind met Minute No 155/04, P1131, (signed) Station Paymaster Cape Town - The Private Secretary to HE The Lieutenant Governor Pretoria, No 4285 The Treasury 15 August 1903; NAB, Pretoria: GOV 629 PS 401, Captain A.A. McHardy Commanding Somaliland Burgher Contingent - Military Secretary io His Excellency the High Commissioner, Durban, 17 July 1903 ; $\underline{\mathrm{Ibid}}$, No MS/566/03 Lieut-Colonel Military Secretary SA, High Commissioner's Office Johannesburg - The Assistant Military Secretary Army Headquarters Pretoria, 21 October 1903; Official History, vol I, p 200.

114 NAB, Pretoria: GOV 629 PS 401, Telegram No 1, Secretary of State London - Governor Johannesburg, 18 June 1903.

115 NAB, Pretoria: GOV 629 PS 401, Transvaal No 730, Copy 22101/1903, Pressing, Fred Graham Colonial Office - The Under Secretary of State War Office, Downing Street, 18 June 1903.

116 NAB, Pretoria: GOV 629 PS 401, Telegram No 1, Secretary of State London - Governor Johanesburg, 18 June 1903; Ibid, Brief, Captain G.R. Kewick - Henley, 26 June 1903; NAB, Pretoria: LTG, Houer 165, Lêer F1, (Code Telegrams Secretary of State 1 June to 4 July 1903), No 565 Boers returning after serving in Somaliland, Copy of Telegram no 2, Governor Johannesburg - Secretary of State London, 30 June 1903; I. Uys, South African Military Who's Who, 1452-1992, pp 31,139. 
aan die War Office voorgestel dat luitenant C.J. Scott, sersant A.S. Donaldson en die manskappe W.M. Scott en J. Hattingh deur Goewerneur Alfred Milner vergoed moes word vir die goeie diens wat hulle in Somaliland gelewer het. Manning het egter nie gespesifiseer wat die vergoeding moes behels nie. ${ }^{117}$

Voor die Somaliland Burgher Contingent se aankoms in Suid-Afrika, het die Britse militêre owerhede in Suid-Afrika besluit om die kontingent vyf dae se ekstra loon toe te staan. In der waarheid het die kontingent slegs vier dae se ekstra loon ontvang toe die eenheid in Durban ontbind is. Kaptein G.R. Kewick, die Assistent Militêre Sekretaris, het verklaar dat: "The five days pay was not meant as a gratuity but simply so that the men might have some thing [sic] in their pockets, for their railway journey ie for food etc."118

Kaptein Bonham is, voordat hy saam met die Somaliland Burgher Contingent Suid-Afrika verlaat het in Januarie 1903, deur Goewerneur Alfred Milner en Joseph Chamberlain in kennis gestel dat dit beide here se wens was om die lede van die kontingent wat hulle gedurende die veldtog uitstekend van hulle taak sou kwyt te vergoed. Aan die begin van Junie het kaptein Bonham so 'n naamlys saamgestel en die lede volgens drie kriteria beoordeel: "Specially recommended ", "Recommended" en "no comment". Kaptein Bonham het die Britse owerhede aangemoedig om veral dié lede wat hy onder die groep "Specially recommended" ingedeel het, moes bystaan om werk te kry of grond te bekom waarop hulle kon boer. Dié wat onder die groep "Recommended" ingedeel is, moes deur die Britse owerhede in diens geneem word of andersins ' $n$ klein bonus ontvang. Geen regeringshulp is vir die lede in die vooruitsig gestel wat onder "no comment " ingedeel is nie. Veral Goewerneur Alfred Milner was gretig om die lede wat spesiaal aanbeveel is deur kaptein Bonham te help om na die oorlog weer hul voete te vind. Veertien van die lede van die kontingent is spesiaal aanbeveel. Sewe van hulle wou in die Staatsdiens opgeneem word en sewe lede was begerig dat die Departement van
Lande (Land Department) hulle moes bystaan om plase te bekom. Vir twintig lede van die kontingent is daar geen spesiale vergoeding in die vooruitsig gestel nie. ${ }^{119}$

Voor die Somaliland Burgher Contingent in SuidAfrika aangeland het, het die Hoofbetaalmeester (Chief Paymaster) in Kaapstad ' $n$ telegram aan die War Office - wat onder andere die finansiële sake rakende die veldtog gereël het - gestuur om te verneem of die kontingent met hul aankoms in SuidAfrika enige spesiale vergoeding moes ontvang. Die kantoor het egter teen so ' $n$ stap besluit en aangevoer: "The operations which have taken place in Somaliland are not of such a nature that, as at present advised, Mr. Brodrick would propose to issue a War Gratuity to the troops engaged."120

Joseph Chamberlain was ook nie ten gunste van ' $n$ spesiale vergoeding bo en behalwe die vasgestelde soldy vir die kontingent nie. Chamberlain het gevoel dat so ' $n$ vergoeding die lede van die kontingent onregverdiglik bo ander lede van die Somaliland Field Force sou bevoordeel. Hy het die standpunt gehuldig dat die uitreiking van ' $n$ medalje en die vergoeding van die leiers van die kontingent voldoende sou wees. Chamberlain het egter nie gespesifiseer wat hierdie vergoeding moes wees nie. ${ }^{121}$

Goewerneur Alfred Milner was van mening dat die beoogde vyf dae ekstra betaling te min was. Milner het die War Office teen die einde van Junie versoek om aan elke lid van die kontingent ' $n$ spesiale vergoeding van een maand se ekstra betaling toe te staan. Die Goewerneur het gemeen dat dit die War Office nie meer as $£ 1000$ sou kos nie. Joseph Chamberlain wou nie gehad het dat die kontingent ' $n$ kontant bedrag as vergoeding ontvang nie maar dat die lede eerder elkeen ' $n$ stuk grond om op te boer gegee moes word. Milner het nie met Chamberlain saamgestem nie. Die Goewerneur het gereken dat dit ' $n$ lang tyd sou neem om grond vir die terugkerende soldate te verkry. Milner het verklaar: "...the extra pay, though of far less real benefit to the men, is of much greater immediate effect as a

117 NAB, Pretoria: GOV 629 PS 401, Transvaal No 865, Copy 0165/3095 (MS3), Guy Fleetwood Wilson War Office - The Under Secretary of State Colonial Office, London SW, 30 July 1903; Ibid, Telegram No 1, Secretary of State London - Governor Johannesburg, 1 August 1903; Official History, vol I, p 197.

118 NAB, Pretoria: GOV 629 PS 401, Brief, G.R. Kewick - Henley, 6 July 1903; Ibid, Brief, G.R. Kewick - Henley, 26 June 1903 ; NAB, Pretoria: LTG, Houer 114, Lêer 102/3 vol II, (Somaliland Matters, Boer Gratuity), 4123 Somaliland Boer Contingent, The Military Secretary SA High Commissioner's Office Johannesburg - Lieutenant-Governor's Office R-B, Pretoria, 18 September 1903 , Private Secretary.

119 NAB, Pretoria: GOV 629 PS 401, Captain Walter Bonham - The Military Secretary to His Excellency The High Commissioner South Africa, Upper Sheikh, Somaliland, 1 June 1903; NAB, Pretoria: LTG, Houer 114, Minute No 14/1351, G. Geoffrey Robinson Private Secretary Governor's Office - The Private Secretary to HE the Lieutenant-Governor Pretoria, Johannesburg, 29 July 1903 : NAB, Pretoria: GOV 629 PS 401, Brief, Governor's Office - Rt Hon Sir Albert Hime Prime Minister of Natal, 29 July 1903.

120 NAB, Pretoria: GOV 629 PS 401, Transvaal No 730, Copy 0165/2871 F2, Guy Fleetwood Wilson War Office -The Under Secretary of State Colonial Office, London SW, 16 June 1903; Official History, vol I, p 118. St John Brodrick was die Britse Minister van Oorlog.

121 NAB, Pretoria: GOV 629 PS 401, Transvaal No 730, Copy 22101/1903, Pressing, Fred Graham Colonial Office - The Under Secretary of State War Office, Downing Street, 18 June 1903. 
demonstration $\alpha$ [sic] it would be a real pity if the amount of it looked mean."122

Chamberlain het egter later sy houding jeens ' $n$ kontantvergoeding verander. Teen 26 Junie het hy teenoor Milner die hoop uitgespreek dat indien moontlik kaptein Bonham se aanbevelings uitgevoer moes word en op 2 Julie Milner laat weet: "If, however, on reconsideration you think a gratuity best I will endeavour to get War Office to increase the amount."123 Goewerneur Milner het Chamberlain hierop laat weet dat hy sy bes sou doen om die kwessie van die toekenning van grond op te los. Die Goewerneur was steeds vasberade om die toekenning van ' $n$ spesiale oorlogsvergoeding deur te voer. Gevolglik het Milner Chamberlain se toestemming gevra om lede van die kontingent uit SuidAfrikaanse fondse te vergoed. Chamberlain het die Goewerneur toestemming verleen om tot so 'n stap oor te gaan. Twee dae nadat die Somaliland Burgher Contingent Durban bereik het, het die Luitenant-Goewerneur en die Uitvoerende Raad van die Transvaal Kolonie ' $n$ spesiale oorlogsvergoeding van ' $n$ maand se addisionele betaling aan lede van die kontingent toegestaan. Ook die Oranjerivier Kolonie het so ' $n$ vergoeding aan dié kolonie se burgers in die kontingent toegestaan. Die voorwaarde verbonde aan die toekenning van die bedrag was dat ' $n$ applikant via Durban na SuidAfrika as ' $n$ lid van die Somaliland Burgher Contingent moes teruggekeer het. ${ }^{124}$

"n Spesiale "Somaliland Boer Contingent Account" is by "The National Bank of South Africa Limited" in Pretoria oopgemaak waaruit die vergoedings betaal sou word. Die fondse het gekom uit die "Miscellaneous F. Special Payments on the Estimates 1903-1904". Die lede van die kontingent moes hulle aansoeke om vergoeding rig aan die Privaat Sekretaris van die Luitenant-Goewerneur in Pretoria. Die ontslagsertifikaat wat lede tydens die ontbinding van die kontingent in Durban ontvang het, moes so ' $n$ aansoek vergesel. ${ }^{125}$

Aan die einde van Julie 1903 het die War Office sy houding jeens ' $n$ spesiale vergoeding vir die Somaliland Burgher Contingent verander. Die kantoor wou gehad het dat die Koloniale Regering in SuidAfrika die vier bogenoemde lede van die kontingent moes vergoed, wat brigadier-generaal W.H. Manning spesiaal uitgesonder het; hulle moes of met hervestiging of met indiensneming in die staat bygestaan word. Die Goewerneur se kantoor in SuidAfrika het die koloniale kantoor egter laat weet dat die Transvaalse Regering reeds aan elke lid van die kontingent ' $n$ spesiale vergoeding toegestaan, het. Wat die kwessie van hervestiging betref, het Arthur Lawley, die Luitenant-Goewerneur van die Transvaal Kolonie, so geantwoord: "I am afraid that it is impossible for this Government to entertain the proposal that grants of land should be made to these men." Arthur Lawley het ook nie gedink dat die lede van die kontingent "...as great a claim upon this Government as those who served in the late Transvaal war" gehad het nie. ${ }^{126}$ Lawley het hier na die Boere verwys wat aan Britse kant gedurende die Anglo-Boereoorlog geveg het. Die LuitenantGoewerneur het bygevoeg dat beloftes van grond wat deur sekere offisiere tydens werwing aan lede van die Somaliland Burgher Contingent gemaak is, nie nagekom kon word nie. Die geval van Scott Harden wat vroeër reeds genoem is, is ' $n$ goeie voorbeeld. Dit blyk ook dat die Transvaalse Regering nie in staat was om ' $n$ groot aantal van die lede van die kontingent van werk te voorsien nie. ${ }^{127}$

Lede van die kontingent het lank na afloop van die veldtog steeds aansoek gedoen vir 'n spesiale oorlogsvergoeding. In November 1904 het 'n Britse weermagorder verklaar dat eise van die lede van die kontingent deur die Betaalmeester van die Leër

22 NAB, Pretoria: GOV 629 PS 401, Telegram No 3, Governor - Secretary of State, 30 June 1903; Ibid, Telegram No 1, Secretary of State London - Governor Johannesburg, 18 June 1903.

123 NAB, Pretoria: GOV 629 PS 401, Telegram No 1, Secretary of State London - Governor Johannesburg, 2 July 1903; Ibid, Telegram No 3, Secretary of State - Governor Johannesburg, 26 June 1903.

124 NAB, Pretoria: LTG, Houer 165, Lêer F1, (Code Telegrams Secretary of State 1 June to 4 July 1903), No 571 Boers who have served in Somaliland, Copy of Telegram No 3, Matter Most Urgent, Governor Johannesburg - Secretary of State London, 3 July 1903; NAB, Pretoria: GOV 629 PS 401, Telegram No 3, Governor Johannesburg - Secretary of State London, 3 July 1903; Ibid, Telegram No 2, Secretary of State - Governor Johannesburg, 8 July 1903; NAB, Pretoria: GOV 629 PS 401, Telegram No 790, Transvaal Government - Governor ORC, 15 July 1903; Ibid, Private Secretary Lieutenant-Governor's Office - The Military Secretary SA High Commissioner's Office Johannesburg, Pretoria, 18 September 1903; NAB, Pretoria: LTG, Houer 114, Lêer 102/3 vol I, (Capt Scott Hardin War Gratuity-Somaliland), Captain H.S. Scott-Harden, Hotel Victoria, Johannesburg, 15 December 1903; Ibid, Leeer 102/3 vol II, (Somaliland Matters, Boer Gratuity), Transvaal No 413, Governor Milner Governor's Office - The Right Honourable The Secretary of State for the Colonies Downing Street London SW, Johannesburg, 6 June 1904.

125 NAB, Pretoria: LTG, Houer 114, Lêer 102/3 vol II, (Somaliland Matters, Boer Gratuity), The Manager The National Bank of SA Limited - The Private Secretary Lieutenant-Governor's Office Pretoria, Pretoria, 11 November 1903; Ibid, Ex Co Minutes no 3968 , 10 July 1903; NAB, Pretoria: GOV 629 PS 401, No MS/588/03, Lieut-Colonel Military Secretary SA - Messrs Evans and Mynhardt Christiana, High Commissioner's Office Johannesburg, 29 October 1903; Ibid, No MS/588/03, Lieut-Colonel Military Secretary SA Chas McGonigal and others Christiana, High Commissioner's Office Johannesburg, 30 October 1903.

126 NAB, Pretoria: GOV, Houer 140, (Despatches To S of S, 600-679, 3 August 1903-14 Sept 1906), Transvaal No 665, Arthur Lawley The Right Honourable Joseph Chamberlain MPThe Colonial Office London, Governor's Office Johannesburg, 12 September 1903; NAB, Pretoria: GOV 629 PS 401, Telegram No 1, Secretary of State London - Governor Johannesburg, 1 August 1903.

127 NAB, Pretoria: GOV, Houer 140, (Despatches To S of S, 600-679, 3 Aug 1903-14 Sept 1906), Transvaal No 665, Arthur Lawley The Right Honourable Joseph Chamberlain MPThe Colonial Office London, Governor's Office Johannesburg, 12 September 1903. 


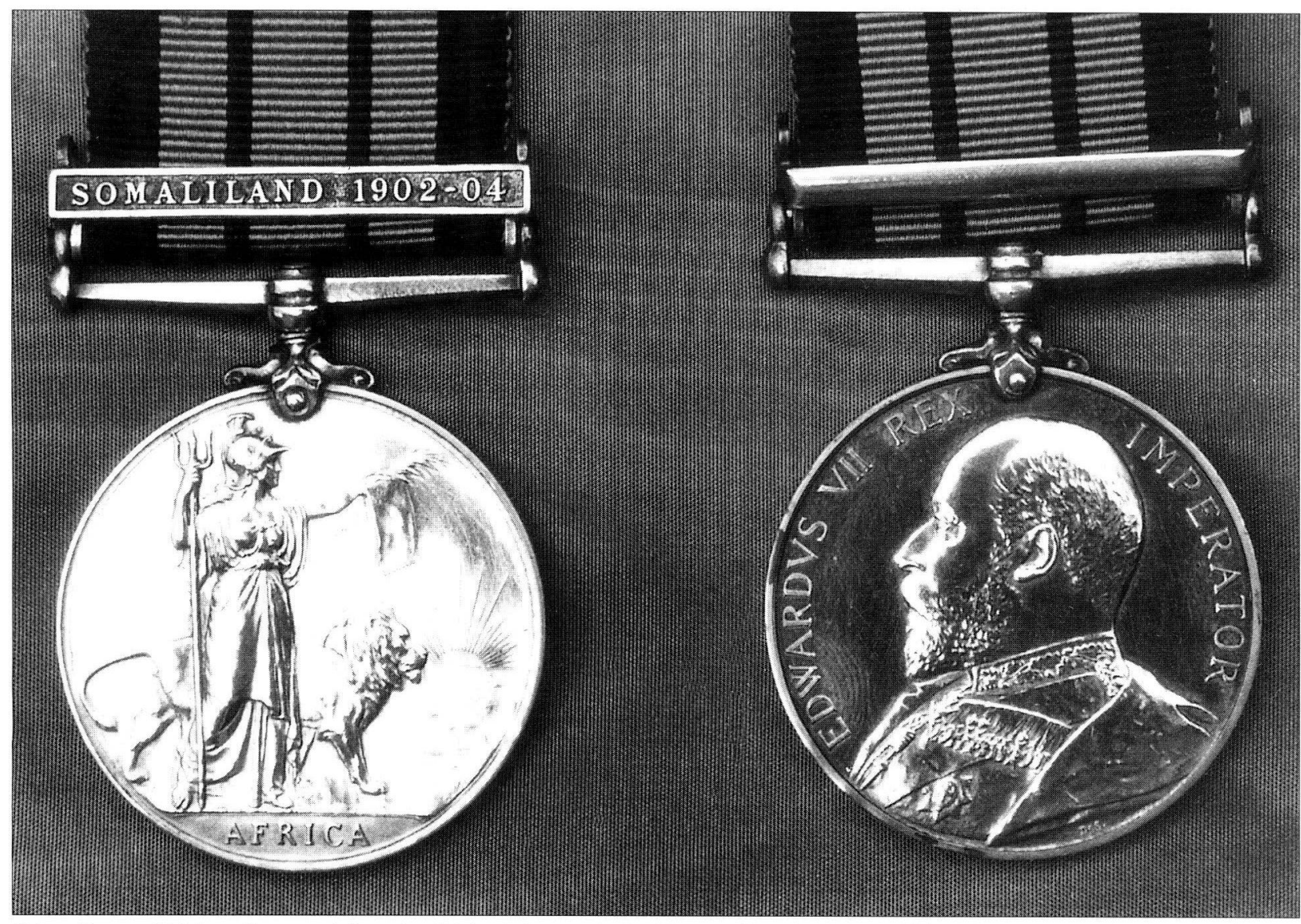

Die silwer "Africa General Service" Medalje met die "Somaliland 1902-04" balkie wat aan lede van die Somaliland Burgher Contingent toegeken is vir hul deelname aan die veldtog teen die Mullah

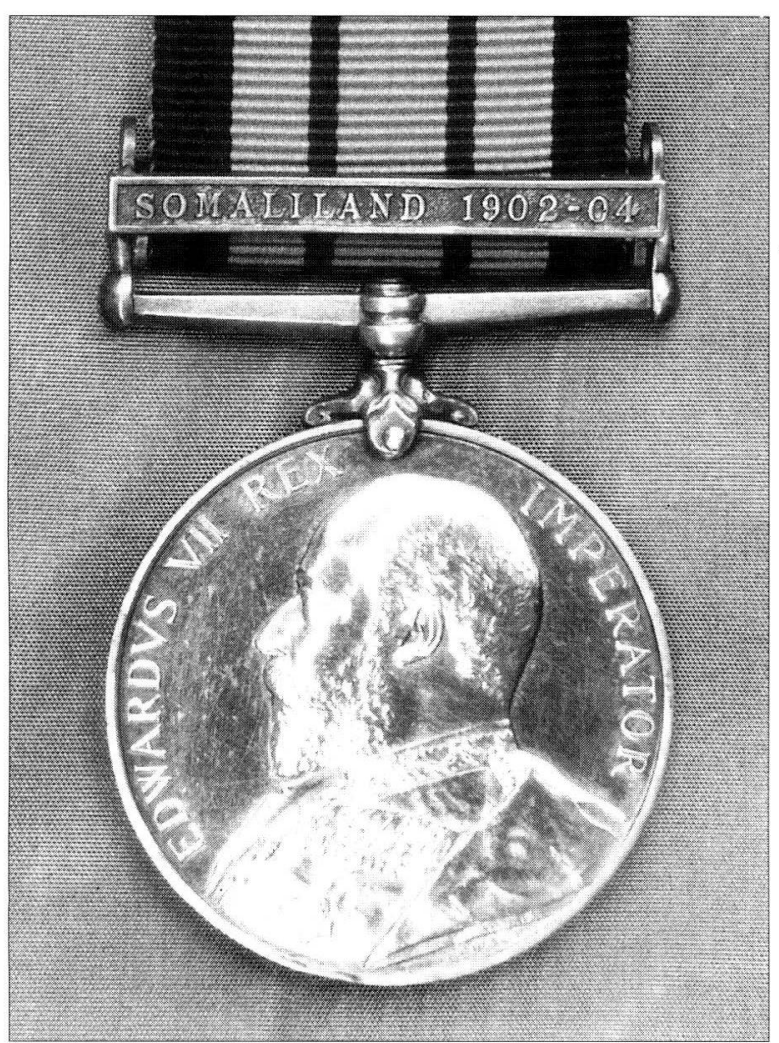

Die voorkant van die "Africa General Service" Medalje met die "Somaliland 1902-04" balkie. Die kop van koning Edward VII, die koning van Brittanje van 1901-1910, is op dié kant uitgebeeld Nasionale Argief

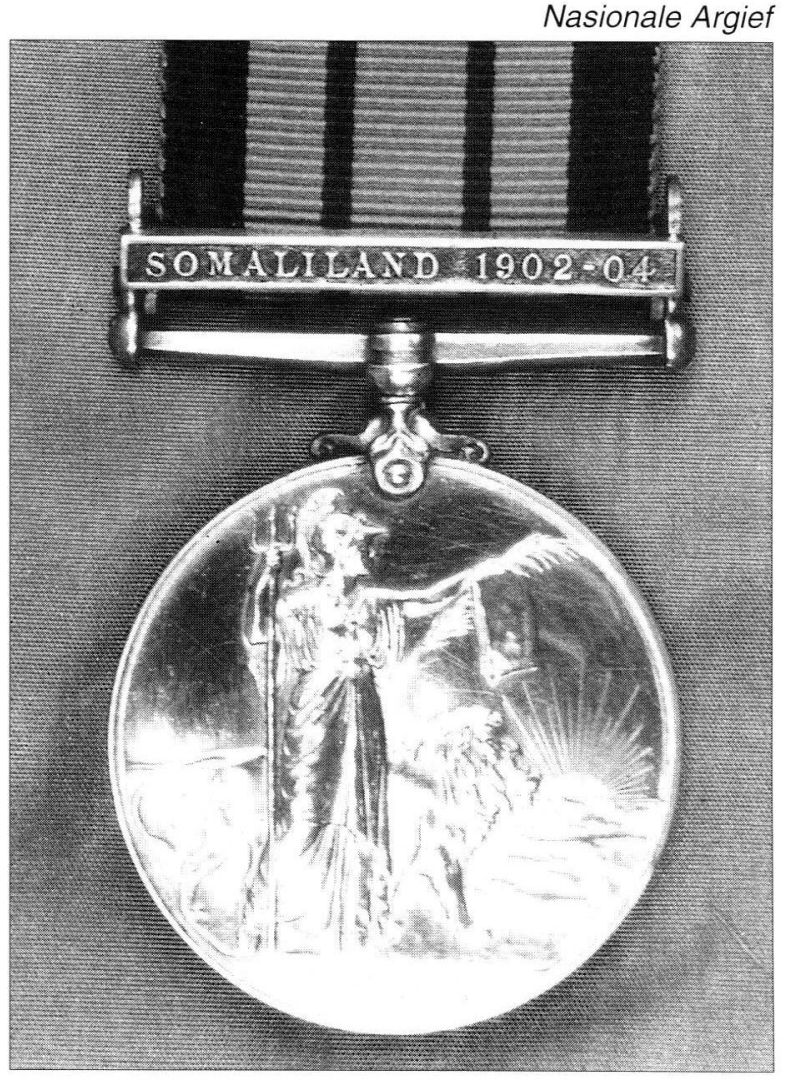

Die agterkant van die "Africa General Service" Medalje met die "Somaliland 1902-04" balkie. Die vrou op die medalje is Britannia, die verpersoonliking van Brittanje

Nasionale Argief 
(Army Paymaster) in Pretoria hanteer sou word. ${ }^{128}$ Dit blyk dat die Raad van die Britse Leër (British Army Council) ook gevoel het dat hulle die Somaliland Burgher Contingentmoes vergoed. Gevolglik het dié raad ' $n$ verdere "Special War Gratuity" aan lede van die Somaliland Burgher Contingent toegestaan wat $£ 1.12$.0d per soldaat beloop het. ${ }^{129}$

Aansoeke om grond wat wel vanaf oud-lede van die kontingent ontvang is, is in ooreenstemming met die Settlers Ordinance van 1902 deur die Kommissaris van Lande oorweeg. Dié ordinansie het voorsiening gemaak vir die beskikbaarstelling van kroongrond aan grondlose persone of plakkers. Die droogte van 1902-1903 het egter die Settlers Ordinance en die toekenning van grond tot mislukking gedoem aangesien die reeds onvrugbare landbougrond verder deur die droogte uitgedor is. ${ }^{130}$

In Oktober 1903 het koning Edward VII van Groot Brittanje verklaar dat dit sy wens was dat die Somaliland Burgher Contingent die eerste ontvangers moes wees van ' $n$ medalje wat hy beoog het om aan veterane van die veldtog in Somaliland toe te ken. Die lede van die kontingent is hierop deur die silwer "Africa General Service" Medalje met die "Somaliland 1902-04" balkie vereer vir hulle deelname aan die veldtog in Somaliland. ${ }^{131}$

Goewerneur Alfred Milner wou ook ekonomiese voordele uit die veldtog in Somaliland trek. Hy wou tienduisend skape vanaf Somaliland na die Transvaal invoer. Die Britse ministerie van buitelandse sake het egter aan die begin van Junie 1903 verklaar dat daar nie genoeg skape in Somaliland gebuit is om aan hierdie wens van Milner uitvoering te gee nie. Die Goewerneur wou moontlik die skape invoer om die tekort aan veestapels na afloop van die Anglo-Boereoorlog aan te vul. ${ }^{132}$

\section{Slot en Gevolgtrekking}

Op 21 Desember 1920 het die Mullah te sterwe gekom. Alhoewel daar na die Derde Ekspedisie nog twee amptelike ekspedisies teen die Mullah geloods is en alhoewel hy by verskeie geleenthede ' $n$ nederlaag gely het, kon die Britte nie sy mag as leier finaal breek nie. Kort voor sy dood het die Mullah en sy volgelinge dertien nuwe forte te Imi aan die Shebelle-rivier in Ethiopië opgerig. Alhoewel daar periodes was waartydens die twee antagoniste nie teen mekaar geveg het nie, het 20 jaar se vyandelikhede eers met die dood van die Mullah in 1920 tot ' $n$ einde gekom. ${ }^{133}$

Dit is opmerklik dat die Britte in Suid-Afrika en in Somaliland van die plaaslike bevolking in hul stryd aangewend het. In Suid-Afrika is Afrikaanssprekendes in die National Scouts en Farmers' Guard aangewend en in Somaliland het die Britte Somaliërs in die King's African Rifles en Somali Mounted Infantry aangewend. Hierdie vrywilligers het gevolglik teen hul eie mense geveg.

Die spesiale vergoeding wat aan die Somaliland Burgher Contingent toegestaan is, moet binne die konteks van Goewerneur Alfred Milner se verengelsings- en heropbouprogram in die Transvaal verstaan word. Milner wou deur die beleid van verengelsing in die voormalige Boere Republieke toe te pas, verseker dat ' $n$ toekomstige selfregerende Suid-Afrika ' $n$ lojale pro-Britse staat sou wees. Milner wou veral die Transvaal Kolonie vir sy beleid van verengelsing aanwend. Omrede die Transvaal ekonomies die mees ontwikkelde kolonie in SuidAfrika was, wou Milner die ekonomiese potensiaal van hierdie gouddraende streek verder ontwikkel en deur middel van emigrasie uit Brittanje die Britse karakter van die kolonie verder versterk. Die Afrikaners in die Oranje-rivier Kolonie en Kaap Kolonie sou dan verplig wees om by die ekonomiese dominante en pro-Britse Transvaal in te val. Milner was oortuig dat hy die goeie trou van die Afrikaners kon wen deur hulle goed te behandel deur hulle byvoorbeeld op finansiële gebied en in die landbou by te staan. ${ }^{134}$

Die Goewerneur het dalk gemeen dat deur ' $n$ spesiale vergoeding aan die Somaliland Burgher Contingent toe te staan hy die Afrikaners in die kontingent se goedgesindheid kon wen. Dit sou ook vir ander Afrikaners ' $n$ aanduiding wees dat Brittanje lojale onderdane vergoed. Ook Joseph Chamberlain het hierdie beskouing gedeel.

128 NAB, Pretoria: LTG, Houer 114, Lêer 102/3 vol II, (Somaliland Matters, Boer Gratuity), Army Order 186 no 13 of November 1904

129 NAB, Pretoria: LTG, Houer 114, Lêer 102/3 vol II, (Somaliland Matters, Boer Gratuity), LG 102/3, Private Secretary LieutenantGovernor's Office - Percy Moojen Esq 65 College Lane Off Park Street, Pretoria, 4 January 1905; Ibid, P/3497, Lieut-Colonel District Paymaster - The Secretary to the Lieut-Governor Transvaal Colony Pretoria, Pretoria, 7 April 1907.

130 S.E. Katzenellenbogen, Reconstruction in the Transvaal, in P. Warwick (red), ea, The South African War, p 346; NAB, Pretoria: GOV 629 PS 401, Minute No 13241, D. Polloch Secretary For Lands - Private Secretary to HE the Lieutenant-Governor Pretoria, Land Department, Pretoria, 10 October 1903; Ibid, Minute No LG 4123, (Somaliland Boer Contingent), Private Secretary Lieutenant-Governor's Office - The Military Secretary SA High Commissioner's Office Johannesburg. Pretoria, 18 September 1903.

131 NAB, Pretoria: LTG, Houer 114, Lêer 102/8, (Somaliland Affairs:Medals), Copy 68/E Africa/75 AG2 CR/5370/1, F. Howard War Office - The General Officer Commanding the Forces in South Africa Pretoria, London SW, 19 October 1903; E.G.M. Alexander ea, South African Orders, Decorations and Medals, p 101; L.L. Gordon, British Battles and Medals, 4th ed, pp 304-305.

132 NAB, Pretoria: GOV 629 Leeer PS 1, (Suggested Export of Sheep from Somaliland to Transvaal 4/3-6/3), Clement L.E. Hill - The Under Secretary of State Colonial Office, Foreign Office, 3 June 1903

133 I.M. Lewis, History of Somaliland, pp 70-80.

134 S.E. Katzenellenbogen, Reconstruction in the Transvaal, in P.Warwick (red) ea, The South African War, pp 341-342. 
Dit blyk dat Brittanje dankbaar was vir die diens wat die kontingent in Somaliland verrig het. Die toekenning van ' $n$ spesiale vergoeding - bo en behalwe 'n vasgestelde soldy - en ' $n$ medalje is bewyse hiervan. Selfs die Koning van Groot Brittanje was begerig dat die kontingent die eerste ontvangers van 'n medalje moes wees wat die veldtog sou herdenk.

Elf jaar later sou Afrikaners saam met Engelssprekende Suid-Afrikaners en swart Suid-Afrikaners weereens as vrywilligers hul lewens vir die Britse Ryk aflê. Tydens die Eerste Wêreldoorlog (19141918) sou nagenoeg 11000 Suid-Afrikaners hul lewens in diens van Brittanje aflê.

\section{Bronne}

\section{PRIMÊRE BRONNE}

\section{NAB, PRETORIA}

\section{ARGIEF VAN DIE HOË KOMMISSARIS 1890-1925}

HC, Houer 2, Lêer 45, SAC, (Various 1 Jan 1902-March 1903).

HC, Houer 66, Lêer 121 1A, (Volunteer Contingent for Somaliland).

\section{ARGIEF VAN DIE LUITENANT-GOEWERNEUR VAN} TRANSVAAL KOLONIE 1902-1907

LTG, Houer 114, Lêer 102/3, vol I, (Capt Scott Hardin War Gratuity-Somaliland); Lêer 102/3 vol II, (Somaliland Matters, Boer Gratuity); Lêer 102/4, (Recruiting for Somaliland); Lêer 102/6, (RH Chase re services for Somaliland); Lêer 102/8, (Somaliland Affairs: Medals); Minute No 14/1351; Dokumente saamgebind met Minute No 155/04.

LTG, Houer 165, Lêer F1, (Code Telegrams Secretary of State 1 June to 4 July 1903)

\section{ARGIEF VAN DIE SEKRETARIS VAN DIE GOEWERNEUR} VANTRANSVAAL KOLONIE 1901-1910

GOV, Houer 140, (Despatches To S of S, 600-679, 3 August 1903-14 Sept 1906).

GOV, Houer 622, Lêer PS 391, vol I (Omnium Gatherum Report for 1902 Correspondence).

GOV, Houer 629, Lêer PS 1, (Suggested Export of Sheep from Somaliland to Transvaal 4/3-6/3); Lêer PS 401, (Somaliland. Export of sheep to the Transvaal, Somaliland Contingent).
ARGIEF VAN DIE STAFOFFISIER, KRYGSGEVANGENES, KAAPSTAD 1900-1903

SOPOW, Houer 63, Lêer PR A6013, (Re POW on

SS Dunera with Commando in Somaliland).

MIKROFILM CL 364 m 2215, Deel 74 no 7231.

MIKROFILM CL 364 m 2215, Deel 74 no 7233.

MIKROFILM CL 364 m 2215, Deel 75 no 7263.

\section{SEKONDÊRE BRONNE}

BODIN, L., The Mad Mullah of Somaliland, Part 1: Introduction, the First and Second Expeditions. Soldiers of the Queen 24, Feb 1981.

ALEXANDER, E.G.M., ea, South African Orders, Decorations and Medals. Cape Town, 1986.

BENBOW, C.H., Boer Prisoners of War in Bermuda, 2nd ed. Bermuda, 1982.

DENOON, D., A Grand Illusion: The failure of imperial policy in the Transvaal Colony during the period of reconstruction 1900 1905. London, 1973.

GENERAL STAFF, WAR OFFICE, Official History of the Operations in Somaliland 1901-1904, vol I. London, 1907.

GORDON, L.L., British Battles and Medals, 4th ed. London, 1971.

GRUNDLINGH, A.M., Collaborators in Boer Society, in P. Warwick (red) ea, The South African War: The Anglo-Boer War 1899-1902. Essex, 1980.

GRUNDLINGH, A.M., Die Vrystaatse en Transvaalse Burgers wat die Republikeinse oorlogspoging vanaf 1900 versaak het: hulle rol en posisie gedurende die tydperk 1900 tot 1907. Ongepubliseerde MA-verhandeling, UNISA, 1976.

HALLOWS, I.S., Regiments and Corps of the British Army. London, 1991.

HAMILTON, A., Somaliland. Connecticut, 1970. (Aanvanklik gepubliseer in 1911 deur Hutchinson and Company, London).

JARDINE, D., The Mad Mullah of Somaliland. London, 1923.

KATZENELLENBOGEN, S.E., Reconstruction in the Transvaal, in P. Warwick (red) ea, The South African War: The AngloBoer War 1899-1902. Essex, 1980.

LEWIS, I.M., The Modern History of Somaliland: From Nation to State. London, 1965.

PAKENHAM, T., The Boer War, 4th ed. London, 1992.

PRETORIUS, F., Kommandolewe tydens die AngloBoereoorlog 1899-1902. Kaapstad, 1991.

SHEIK-ABDI, A., Divine Madness: Mohammed Abdulle Hassan (1856-1920). London, 1993.

SMITH, K. en F.J. NÖTHLING, Afrika noord van die Limpopo: Die imperiale wedervaringe sedert 1800. Pretoria, 1988.

UYS, I., South African Military Who's Who 1452-1992. Germiston, 1992. 